\title{
The selective cytotoxicity of the alkenyl glucosinolate hydrolysis products and their presence in Brassica vegetables.
}

\author{
Nurul H.A. Kadir ${ }^{1,3}$, Rhiannon David ${ }^{2}$, John T. Rossiter ${ }^{1}$ and Nigel J. Gooderham².
}

Cell and Molecular Biology ${ }^{1}$, Computational and Systems Medicine ${ }^{2}$, Imperial College London, SW72AZ, UK and School of Food Sciences and Technology, Universiti Malaysia Terengganu, Malaysia ${ }^{3}$.

Correspondence to:

Professor Nigel J Gooderham

Computational and Systems Medicine Imperial College London Sir Alexander Fleming Building London SW7 2AZ Email: n.gooderham@imperial.ac.uk Tel: (44)02075943188

\footnotetext{
Abbreviations:

CYP - cytochrome P450; ROS - Reactive oxygen species; ITC - isothiocyanate; ETN epithionitrile; ESP - epithiospecifer protein; AhR - Arylhydrocarbon receptor; 2,3PROP-ITC - 2-propenylisothiocyanate; 3,4-BUT-NIT - 3,4-butenylnitrile; 3,4-ETBUTNIT - 3,4-epithiobutylnitrile; 3,4-BUT-ITC - 3-butenylisothiocyanate; 4,5-PENT-NIT - 4pentenyInitrile; 4,5-ETPENT-NIT - 4,5-epithiopentyInitrile; carboxy-H2DCFDA - 6Carboxy-2'7'-dichlorodihydrofluorescein diacetate; PBS - Phosphate buffered saline; DMSO - Dimethyl sulphoxide; Rho123 - Rhodamine 123; EROD - Ethoxyresorufin-Odeethylase; OPA - O-phthaldialdehyde; GSH - Reduced glutathione.

Keywords:

Brassica; chemoprevention; cytotoxicity; glucosinolate hydrolysis products.
} 


\section{Introduction}

Epidemiological studies have shown that dietary cruciferous vegetables may reduce the risk of cancer development and this protective effect is attributed in part to glucosinolate degradation products. Clinical studies have reported that higher intakes of cruciferous vegetables may reduce the risk of lung, colorectal, breast and prostate cancers and major chronic diseases (Willett 2000) (Feskanich et al. 2000) (Voorrips et al. 2000) (Gupta et al. 2014) (Zhao et al. 2001).

When Brassica plant tissue is disrupted by chopping or chewing, plant myrosinase comes into contact with glucosinolates, causing cleavage of the thioglucoside linkage producing an unstable thiohydroximate $O$-sulfonate that rearranges to yield hydrolysis products such as isothiocyanate (ITC), nitrile and epithionitrile (ETN) (Figure 1). The aglycone most frequently undergoes a Lossen rearrangement to produce ITC (Bones and Rossiter 1996; Bones and Rossiter 2006; Hanschen et al. 2014). If the glucosinolate side chain contains a double bond (alkene) in the chemical structure, in the presence of epithiospecifer protein (ESP) and ferrous ions, the thiohydroximate rearranges to produce an ETN and nitrile (Bones and Rossiter 2006). ESP is more sensitive to thermal processing than myrosinase and short periods of steaming can alter degradation profiles to increase ITCs with a marked reduction in nitriles and ETNs (Sarikamis et al. 2006). Thus ETNs and nitriles are more likely to be formed in raw vegetables (Abd Kadir 2013; Kyung et al. 1995) such as in salads where for example cabbage is used. Commonly Brassica vegetables are boiled to the extent where myrosinases are deactivated. In this case the intestinal microflora can metabolise glucosinolates to give ITCs and nitriles (Fahey et al. 2012) (Luang-In et al. 2014) (Saha et al. 2012). While a great deal of data exists for anti cancer properties of ITCs, sulforaphane in particular (Hanschen et al. 2014) (Nakamura and Miyoshi 2010), there is far less information on other types of hydrolysis products such as ETNs and nitriles. In the seventies and eighties there was concern that ETNs being similar in structure to epoxides i.e. a three membered ringed heterocyle with sulfur replacing oxygen, might have similar toxicities. Few studies have revealed any negative aspects of sulforaphane although recently it has been shown that nucleotide excision repair is impaired (Piberger 
et al. 2014). Ring strain and the electrophilic nature of the carbon adjacent to the sulfur atom enables easy ring opening reactions with nucleophiles such as glutathione and DNA components resulting in alkylation (Druckrey et al. 1970; Luthy and Benn 1980). Studies at this time showed that ETNs were toxic in rats but at relatively high doses compared to those that might be taken in the human diet (Brocker et al. 1984) (Luthy et al. 1980) (Nishie and Daxenbichler 1980). Other work suggests that ETNs might be mutagenic while also slightly inhibitory to mutagenicity caused by benzpyrene (Uda et al. 1992). More recently the potential benefits of ETNs have been explored where it has been shown that 3,4-epithiobutylnitrile was the most potent inducer of cytoprotective enzymes of the ETNs tested (Kelleher et al. 2009).

Isothiocyanates are cancer chemopreventive in several animal models; proposed mechanisms include modulation of xenobiotic-metabolising enzymes by inhibition of cytochrome P450 enzymes (CYPs) (Smith and Yang 2000), inducing phase II detoxifying enzymes such as glutathione $S$-transferases (GST) and NAD[P]H: quinone acceptor oxidoreductase 1 (NQ01), activating NF-E2 related factor 2 (NrF2) and the arylhydrocarbon receptor (AhR) (Hayes et al. 2008). Studies on structure-activity relationship in vivo and in vitro have demonstrated that the length of the alkyl chain of arylalkyl ITC also plays a role in the inhibition of CYP enzymes and increases their chemopreventive efficacy (Hayes et al. 2008; Munday et al. 2008; Zhang and Talalay 1994). Isothiocyanates such as phenethylisothiocyanate and 4methylsulfinylbutylisothiocyanate (sulforaphane) have been shown to be capable of inducing cell cycle arrest and cell death in cancer cells such as human prostate cancer cell lines(Hayes et al. 2008) (Singh et al. 2004); bladder cancer cells (UM-UC-3) (Abbaoui et al. 2012); and human leukaemia cells (HL-60) (Xu and Thornalley 2000).

For this study we have selected the potential hydrolysis products (Figure 1) of two glucosinolates 2-propenyl- and 3-butenylglucosinolate which are found in Brassica vegetables. We have used the MCL-5 human lymphoblastoid cell line that has been engineered to express CYPs 1A1, 1A2, 2E1, 2A6, 3A4 (Crespi 1991). The cHol cell line is identical to the MCL-5 line, but does not express the transfected CYP genes. The two 
cell lines, differing only in the metabolic competency, facilitate study of the role of CYP enzymes in xenobiotic oxidation, formation of reactive oxygenated intermediates (ROI), depletion of reduced glutathione, cellular damage, apoptosis and mutagenicity (Crespi 1991). Here we have examined the involvement of oxidative stress and glutathione depletion leading to cell death induced by the glucosinolate hydrolysis products and show that cytotoxicity is dependent on the nature of the hydrolysis product.

\section{Material and Methods \\ Chemicals}

RPMI 1640, L-glutamine, penicillin, streptomycin and hygromycin B were purchased from Invitrogen Corporation (Paisley, Scotland, UK). AlamarBlue $\AA^{\circledR}$ reagent and histidinol were purchased from Sigma Aldrich Company (Poole, England, UK). All other chemicals unless stated in the text were obtained from Sigma Aldrich Company. 2Propenylisothiocyanate and 3-butenyInitrile were purchased from Sigma-Aldrich and fractionally distilled. The purity of compounds was assessed using GC-MS (Hewlett Packard 6890 GC linked to a 5973 MSD). Analysis was carried out on a Rtx®-200MS (Crossbend® trifluoropropylpolysiloxane) $(30 \mathrm{~m} \times 0.25 \mathrm{~mm}) 0.25 \mu \mathrm{m}$ film thickness. The $\mathrm{GC}$ was programmed at an initial temperature of $50^{\circ} \mathrm{C}(5 \mathrm{~min})$ and to a final temperature of $270^{\circ} \mathrm{C}$ (linear gradient, $25 \mathrm{~min}$ ) and held for $5 \mathrm{~min}$.

\section{3-Butenylisothiocyanate (3,4-BUT-ITC)}

3,4-BUT-ITC was synthesised according to the procedures of Ettlinger and Hodgkins (Ellinger 1955). The product was purified by distillation $\left(80^{\circ} \mathrm{C}, 30 \mathrm{~mm} \mathrm{Hg}\right)$ and the structure confirmed by GC-MS and ${ }^{1} \mathrm{H}-\mathrm{NMR}$ spectroscopy. ${ }^{1} \mathrm{H}$ NMR $\left(400 \mathrm{MHz}, \mathrm{CDCl}_{3}\right)$ : $\delta 2.5358$ (q, $2 \mathrm{H}, H-4, J=2.44$ ), 3.6527 (t, $2 \mathrm{H}, H-3, J=6.60), 5.2828(\mathrm{~m}, 2 \mathrm{H}, H-1)$, 5.8880 (ddt, $1 \mathrm{H}, H-2, J=17.04,10.2,6.76)$. MS (EI) $m / z(\%): 72$ (100), $113\left(\mathrm{M}^{+}, 70\right), 55$ (19), 85 (10), $114(1,5)$.

3,4-EpithiobutyInitrile (3,4-ETBUT-NIT) and 4,5-epithiopentyInitrile (4,5-ETPENT-NIT) 
Starting from the bromides (2-propenylbromide and 3-butenylbromide), 3,4-ETBUT-NIT and 4,5-ETPENT-NIT were synthesised according to the procedures described by Luethy et al. (Luethy et al. 1980). The resulting ETNs were purified by column chromatography on florisil. Florisil $(8 \mathrm{~g})$ was washed with pentane and the reaction product (approx $40 \mathrm{mg}$ ) dissolved in ether and applied to the column. The product was eluted (5 $\mathrm{ml}$ fractions) using a sequential mixture of pentane and ether in the ratio of $4: 1$ $(10 \mathrm{ml}), 3: 1(15 \mathrm{ml}), 2: 1(15 \mathrm{ml})$ and finally $1: 1(20 \mathrm{ml})$. The elution of the ETNs was monitored by GC-MS. The ETNs eluted in the 3:1 pentane:ether fraction and were evaporated in a gentle stream of nitrogen gas to give approximately $25 \mathrm{mg}$ of pure ETNs. The purity was confirmed by GC-MS and ${ }^{1} \mathrm{H}-\mathrm{NMR}$ spectroscopy.,4-ETBUT-NIT: ${ }^{1} \mathrm{H}$ NMR (400 MHz, CDCl $)$ ): $\delta 2.4280$ (dd, $1 \mathrm{H}, \mathrm{H}-1, J=5.04,1.64$ ), 2.7013 (dd, $1 \mathrm{H}, \mathrm{H}-1$, $J=6.12,1.60)$, 2.8974 (dq, $2 \mathrm{H}, H-3, J=12.96,5.64), 3.1817(\mathrm{~m}, 1 \mathrm{H}) . \mathrm{MS}(\mathrm{EI}) \mathrm{m} / z(\%)$ : 99(M+ $\left.\mathrm{M}^{+}, 100\right), 72$ (26), 98 (8), 71 (7), 70 (5), 59 (3), 58 (3); 4,5-ETPENT-NIT: $\delta 1.7623$ $(\mathrm{m}, 1 \mathrm{H}), 2.3608(\mathrm{dd}, 1 \mathrm{H}, J=5.36,1.32), 2.4324(\mathrm{~m}, 1 \mathrm{H}), 2.6601(\mathrm{~m}, 2 \mathrm{H}), 3.0920(\mathrm{~m}$, 1H). MS (EI) $m / z(\%): 113\left(\mathrm{M}^{+}, 100\right), 86(18), 80(16)$.

\section{4-PentenyInitrile (4,5-PENT-NIT)}

4,5-PENT-NIT is an intermediate in the synthesis of 4,5-ETPENT-NIT (Luethy et al. 1980 ) and was purified by fractional distillation (bp, 79-81, $98 \mathrm{~mm} \mathrm{Hg}$ ) and the structure confirmed by GC-MS and ${ }^{1}$ NMR (Gribkov et al. 2006; Luethy et al. 1980). ${ }^{1} \mathrm{H}$ NMR (400 $\mathrm{MHz}, \mathrm{CDCl}_{3}$ ): $\delta 2.4908$ (m, 4H), 5.2470 (ddt, $2 \mathrm{H}, J=12.44,5.60,1.20$ ), 5.9107 (ddt, $1 \mathrm{H}$, $J=16.68,10.4,6.28)$. MS (EI) $m / z(\%): 81\left(M^{+}, 89\right), 66(8), 54(100)$.

\section{Cell culture}

The two human B lymphoblastoid cells, MCL-5 (metabolically competent and expressing CYP1A1, 1A2, 2E1, 2A6, 3A4 and epoxide hydrolase) and $\mathrm{cHo} 1$ (no engineered CYP expression) grow in suspension and were used throughout this study. MCL-5 and cHo1 cells were maintained in RPMI 1640 media containing L-glutamine (2 $\mathrm{mM})$, supplemented with horse serum $(45 \mathrm{~mL})$, penicillin/streptomycin $(100 \mu \mathrm{g} / \mathrm{mL})$, hygromicine $\mathrm{B}(200 \mu \mathrm{g} / \mathrm{mL})$ and histinidol $(2 \mathrm{mM})$. Cells were incubated in a $5 \% \mathrm{CO}_{2}$ 
atmosphere at $37^{\circ} \mathrm{C}$. Cell numbers were assessed using a haemocytometer and viability assessed using trypan blue exclusion.

\begin{abstract}
AlamarBlue $\AA^{\circledR}$ assay
Cytotoxicity was assessed using AlamarBlue® assay (Invitrogen, Life Technologies). AlamarBlue ${ }^{\circledR}$ indicator dye changes colour and fluoresces in response to cellular enzymic reduction of resazurin to fluorescent resorufin by viable cells. For both MCL-5 and $\mathrm{cHo} 1$ cells, the reduction is proportional to the number of viable cells present in the sample (data not shown). Briefly, MCL-5 cells were harvested and seeded $\left(10^{5}\right.$ cells/well) in 24 well plates and left overnight in a humidified incubator with a 5\% CO2 atmosphere at $37^{\circ} \mathrm{C}$ to equilibrate. Twenty $\mu \mathrm{L}$ of vehicle control $(96 \%$ ethanol) or test compounds, 2,3-PROP-ITC, 3,4-BUT-NIT, 3,4-ETBUT-NIT, 3,4-BUT-ITC, 4,5-ETPENTNIT and 4,5-PENT-NIT (dissolved in 96\% ethanol) were added into $2 \mathrm{~mL}$ media containing cells and incubated for $48 \mathrm{~h}$. At the end of the incubation period, AlamarBlue $®(200 \mu \mathrm{L}, 0.4 \%)$ was added to each well and incubated for 8 hours. The fluorescence was monitored at $560 \mathrm{~nm}$ excitation wavelength and $590 \mathrm{~nm}$ emission wavelength using a BMG Polarstar fluorimetric plate reader.
\end{abstract}

\title{
Trypan blue exclusion assay
}

Cell number was determined using a haemocytometer and viability evaluated using an assay based on the exclusion of trypan blue dye $(0.4 \%, 100 \mu \mathrm{l})$. Cells were seeded $\left(10^{4}\right.$ cells/well) in 24 well plates and allowed to equilibrate.

\section{Oxidative Stress Measurement using a Diclorofluorescein (DCF) Assay}

Oxidative stress was determined fluorometrically using diclorofluorescein (DCF) (Said et al. 2007); (Shao et al. 2008). Cells $\left(2.0 \times 10^{5}\right)$ were seeded into 24 well plates and equilibrated overnight. 6-Carboxy-2'7'-dichlorodihydrofluorescein diacetate (carboxy$\mathrm{H}_{2}$ DCFDA, $20 \mu \mathrm{L}, 30 \mu \mathrm{M}$ ) in RPMI media ( $1 \mathrm{~mL}$ ) was added to each well and incubated for 30 mins at $37^{\circ} \mathrm{C}$ to load cells, which were then centrifuged (2000 g). Medium was aspirated and the cells washed with phosphate buffered saline (PBS). New RPMI 1640 medium $(990 \mu \mathrm{L})$ was added into each well. Glucosinolate hydrolysis products $(10 \mu \mathrm{L}$ in 
RPMI 1640 media to give a final concentration of 0.1 to $100 \mu \mathrm{M}$ ) were added and the cells were incubated from $0.5 \mathrm{~h}$ to $24 \mathrm{~h}$. Fluorescent measurements (excitation at 485 $\mathrm{nm}$ and emission at $520 \mathrm{~nm}$ ) were taken from $0.5 \mathrm{~h}$ - $24 \mathrm{~h}$ using a BMG Polarstar fluorimetric plate reader. Measurements were recorded for 4 independent cultures.

\section{EROD activity}

EROD activity was measured in a dynamic assay in a pre-heated $\left(37^{\circ} \mathrm{C}\right)$ plate reader with readings taken every $10 \mathrm{~min}$ for up to $120 \mathrm{~min}$. Glucosinolate hydrolysis products in ethanol $(10 \mu \mathrm{L})$ were added into RPMI 1640 phenol red free media $(1 \mathrm{~mL})$ containing cells $\left(2 \times 10^{6}\right)$ to give a final concentration of 0.1 to $100 \mu \mathrm{M}$ and pre-incubated for 40 min at $37^{\circ} \mathrm{C}$. Immediately after pre-incubation, 7-ethoxyresorufin (dissolved in DMSO, $1 \mu \mathrm{L}$ ) was added to each well to give a final concentration of $5 \mathrm{mM}$. CYP1 mediated 7ethoxyresorufin metabolism to resorufin was measured fluometrically (excitation at $560 \mathrm{~nm}$ and emission at $580 \mathrm{~nm}$ ) in a pre-heated plate reader at $37^{\circ} \mathrm{C}$. A resorufin standard curve was generated using resorufin stock solution serially diluted in RPMI 1640 phenol red free media containing cells $\left(2 \times 10^{6}\right)$ cells. As a positive control for CYP1 activity, Aroclor 1254-induced rat liver S9 (20 $\mu \mathrm{g}$ protein) was used in a reaction mixture containing 0.1M Tris-HCL ( $\mathrm{pH} 7.4)$, NADPH (0.5 mM), glucose-6-phosphate (10 $\mathrm{mM}$ ), $\mathrm{MgCl}_{2}$ (2 $\mathrm{mM}$ ), glucose-6-phosphate dehydrogenase (3 units $/ \mathrm{mL}$ ) with 7ethoxyresorufin (5 mM final concentration) to give a final volume of $1 \mathrm{~mL}$. In some experiments, cells were pretreated with 2,3-PROP-ITC $(0-2 \mu \mathrm{M})$ or 3,4-BUT-ITC $(0-$ $75 \mu \mathrm{M})$ for $24 \mathrm{~h}$, then EROD was measured as described above.

\section{Reduced Glutathione}

Cells $\left(2.0 \times 10^{5}\right)$ were plated in 24 well plates containing RPMI 1640 media with supplements. Glucosinolate hydrolysis products in ethanol $(20 \mu \mathrm{L})$, were added into 2 $\mathrm{mL}$ media containing cells to give a final concentration of 0.1 to $100 \mu \mathrm{M}$. The treated cells were incubated for 0.5 to $24 \mathrm{~h}$ at $37^{\circ} \mathrm{C}$. The samples were analysed for reduced glutathione using a method based on that previously described (Hissin and Hilf 1976). The cells were harvested from each well and centrifuged at $2000 \mathrm{~g}$ for $5 \mathrm{~min}$ at $4^{\circ} \mathrm{C}$. The 


\section{Mitochondria membrane permeability}

Rhodamine 123 (Rho123) is a cationic fluorescent dye, which permeates living cells and can be used to measure mitochondrial trans-membrane potential $\left(\Delta \Psi_{\mathrm{m}}\right)$. As previously described (Tang and Zhang 2005), Rh123 is sequestered by normal mitochondria, which then fluoresce; when $\Delta \Psi_{\mathrm{m}}$ is lost, the fluorescence is diminished. We have used this approach to assess $\Delta \Psi_{\mathrm{m}}$ in $\mathrm{cHo} 1$ and MCL-5 cells by fluorimetry at excitation of 500 $\mathrm{nm}$ and emission of $550 \mathrm{~nm}$ using a microplate reader (Polarstar, BMG).

Cells $\left(2 \times 10^{5}\right)$ were seeded in each well of a 24 well plate and equilibrated overnight in a $\mathrm{CO}_{2}$ incubator at $37^{\circ} \mathrm{C}$. To load cells, rhodamine $123(20 \mu \mathrm{L}, 510 \mu \mathrm{M})$ was added to each well with cells in RPMI 1640 media $(1 \mathrm{~mL})$ and incubated for 30 mins. The cells were centrifuged $\left(10 \mathrm{~min}, 5^{\circ} \mathrm{C}, 2000 \mathrm{~g}\right)$, the media was aspirated and replaced with fresh RPMI 1640 media. Glucosinolate hydrolysis products in ethanol $(10 \mu \mathrm{L})$ were 
added into $1 \mathrm{~mL}$ of media containing cells, to give a final concentration of 0.1 to $100 \mu \mathrm{M}$ and incubated for $0.5 \mathrm{~h}$ to $24 \mathrm{~h}$ with periodic fluorescence measurements.

\section{Cell cycle}

Cells $\left(5 \times 10^{5}\right)$ were seeded in 12 well plates containing $5 \mathrm{~mL}$ RPMI media. After an overnight pre-equilibration period, the cells were exposed to the glucosinolate hydrolysis products $(100 \mu \mathrm{M}$ and $10 \mu \mathrm{M})$ for $24 \mathrm{~h}$ to $48 \mathrm{~h}$ in triplicate cultures. Immediately after the incubation period the plates were centrifuged $\left(10 \mathrm{~min}, 2000 \mathrm{rpm}, 5^{\circ} \mathrm{C}\right.$ ), the media was aspirated and replaced with $1 \mathrm{~mL}$ of ice-cold $70 \%$ ethanol and kept at $-20^{\circ} \mathrm{C}$ overnight to fix the treated cells. The fixed cells were harvested by centrifugation ( $5 \mathrm{~min}, 2000 \mathrm{rpm}$, $5^{\circ} \mathrm{C}$ ) then washed with PBS and resuspended thoroughly (to get single cell suspensions) in propidium iodide staining solution containing $5 \mathrm{mg} / \mathrm{mL}$ propidium iodide (PI), $0.1 \mu \mathrm{g} / \mathrm{mL}$ RNase and $0.1 \%$ triton- $x 100$, followed by incubation (30 min, $37^{\circ} \mathrm{C}$ ). Samples were analysed using flow cytometry (BD LSRFortessa, USA) and data were quantified using FlowJo software version 7.0. (Tree Star Inc., OR, USA)

\section{Apoptosis}

Apoptosis analysis was carried out using Alexa® Fluor 488 annexin $\mathrm{V}$ and $\mathrm{Pl}$ dye kit (invitrogen,UK). MCL- 5 cells ( $10^{6}$ cells) were seeded in 6 well plates containing $10 \mathrm{~mL}$ RPMI media. After overnight pre-equilibration, the cells were exposed to glucosinolate hydrolysis products $(100 \mu \mathrm{M})$ for up to $48 \mathrm{~h}$ in triplicate independent cultures. Immediately after the incubation period, the plates were centrifuged (10 min, $2000 \mathrm{rpm}$, $5^{\circ} \mathrm{C}$ ), the media was aspirated and the cells were washed with phosphate buffer saline (PBS). The washed cells were centrifuged to remove PBS then resuspended in annexin-binding buffer (100 $\mu \mathrm{L}$, Invitrogen), followed by addition of Alexa® Fluor 488 annexin $\mathrm{V}(5 \mu \mathrm{L}$, Invitrogen) and PI working solution $(1 \mu \mathrm{L}, 100 \mu \mathrm{g} / \mathrm{mL}$, Invitrogen). The cells were incubated at room temperature in the dark for 15 min then annexin-binding buffer $(400 \mu \mathrm{L})$ was added to give final volume of $500 \mu \mathrm{L}$ and mixed gently on ice. Immediately, the stained cells were analysed by flow cytometry (emission at $530 \mathrm{~nm}$ and excitation at $488 \mathrm{~nm}$ ). The cell populations were analysed using FlowJo 7.0 software. 


\section{RNA Extraction and Quantitative RT-PCR (Q-PCR)}

Following treatment, cells $\left(3 \times 10^{6}\right)$ were collected by centrifugation (200xg, 5 minutes, RT) and the pellet resuspended in $0.5 \mathrm{ml}$ Trizol (Invitrogen, Paisley, UK) for RNA extraction, quantified (Implen nanophotometer, $\mathrm{GmbH}$, Munchen, Germany) and ratios A260/280 and A260/230 used to assess quality. To synthesise cDNA $1 \mu$ l random primers was added to 500ng of RNA (final volume of $15 \mu$ l with RNase/DNase-free $\left.\mathrm{dH}_{2} \mathrm{O}\right)$ and incubated $\left(65^{\circ} \mathrm{C}, 5\right.$ minutes). The mixture was placed on ice before addition of $0.2 \mathrm{mM}$ dNTPs, $5 \mu \mathrm{l} 5 \mathrm{x}$ first strand buffer, $2 \mu \mathrm{l} 0.1 \mathrm{mM}$ DTT and $0.5 \mu \mathrm{l}$ Superscript II reverse transcriptase (Superscript II kit, Life Technologies). Samples were run on a thermocycler $\left(25^{\circ} \mathrm{C}, 10\right.$ minutes; $42^{\circ} \mathrm{C}, 90$ minutes; $70^{\circ} \mathrm{C}, 15$ minutes). CYP1A1 cDNA was amplified using Q-PCR. Primer sequences were as described by Hummerich et al., (Hummerich et al. 2004). As an internal control, endogenous glyceraldehyde-3phosphate dehydrogenase (GAPDH) cDNA from the same cellular extracts was also amplified. cDNA was amplified using Taqman Fast 2x Universal PCR master mix, No AmpErase UNG (Life Technologies) in triplicate. Q-PCR data were analysed using the ABI 7500 Sequence Detection System (Life Technologies) and comparative Ct Method ( $\triangle C T$ Method) (Livak and Schmittgen 2001). Calibration was based on the expression of GAPDH.

Statistical Analysis

A one way analysis of variance followed by a Dunnett's multiple comparison test was used to determine significant differences between groups.

\section{Results}

\section{Effects of glucosinolate hydrolysis products on cell viability}

The cytotoxic effect of the glucosinolate hydrolysis products was examined using the AlamarBlue ${ }^{\circledR}$ assay with the metabolically competent MCL-5 cells and $\mathrm{cHo} 1$ cells. Cells were treated for 48 hours with compounds $(0-100 \mu \mathrm{M})$ then assessed for cell number and viability compared to the vehicle control. The results shown in figure 2 indicate that 
2,3-PROP-ITC is the most cytotoxic of the glucosinolate products examined and induces dose-dependent toxicity in both cell lines. Of the other compounds, 3,4-BUTITC, 3,4-ETBUT-NIT and 4,5-ETPENT-NIT show dose-dependent toxicity in both cell lines but there is little toxicity noted with the other compounds examined (Fig 2). The concentrations of glucosinolate hydrolysis products at which there was a $50 \%$ loss of cell viability (EC50) are shown in table 1. In contrast, 4,5-PENT-NIT increased Alamar Blue reduction in both cell lines at all doses examined and 4,5-ETPENT-NIT and 3,4BUT-ITC both increased reduction in MCL-5 cells at doses $<1 \mu \mathrm{M}$. This increased reduction of Alamar Blue was not due to a significant increase in viable cell number, determined by Trypan Blue exclusion (data not shown), and therefore appears to be a stimulation of the reduction process.

\section{Cytochrome $\mathbf{P 4 5 0}$ activity}

A proposed mechanism whereby the glucosinolate hydrolysis products exert their chemopreventative activity is via inhibition of xenobiotic metabolism. We therefore examined the effect of treating the metabolically competent MCL- 5 cells with each of the glucosinolate hydrolysis products $(0-100 \mu \mathrm{M})$ and measured ethoxyresorufin $\mathrm{O}$ deethylase (EROD), a marker of CYP1A activity. The results show that 2,3-PROP-ITC and 3,4-BUT-ITC inhibit EROD, but only at the highest dose employed (100 $\mu \mathrm{M})$ (Fig 3). Caution must be exercised in interpreting these results as at high doses $(>10 \mu \mathrm{M})$ these ITCs are cytotoxic (Figure 2). In the EROD experiment, the cells were preincubated for 40 mins then EROD dynamically assessed over the next 2 hs. Within this 160 min period, metabolic activity continued but cytotoxicity was increasingly likely to be a confounding factor. All other glucosinolate hydrolysis products failed to significantly affect EROD (Fig 3)

To further explore the effect of the ITCs on CYP activity, we incubated MCL- 5 cells with sub-cytotoxic doses of 2,3-PROP-ITC $(0-2 \mu \mathrm{M})$ for $24 \mathrm{~h}$, then performed the EROD assay. Under these conditions, we observed a statistically significant dose-dependent inhibition of EROD (Fig 4B). To determine whether this inhibition was a direct effect on enzymic activity or altered CYP1A1 gene expression, we used $\mathrm{PPCR}$ to determine 
CYP1A1 mRNA levels and showed treatment had no effect (Fig 4C). In contrast similar experiments with 3,4-BUT-ITC treatment $(0-75 \mu \mathrm{M})$ had no effect on EROD (Fig 4A).

\section{Oxidative stress}

Another proposed mechanism involved in the chemopreventative activity of cruciferous vegetables is induction of oxidative stress. We therefore assessed the effect of treatment of cells with the individual glucosinolate hydrolysis products on the formation of reactive oxygen species (ROS). ROS production after treatment with 2,3-PROP-ITC was more pronounced in the metabolically competent MCL-5 cell line compared to the cHo1 cells. The effect was both temporally and dose-dependent with maximum effect in MCL-5 cells at $24 \mathrm{~h}$ (Fig 5).

None of the other glucosinolate hydrolysis products examined significantly induced ROS activity in either cell line at any of the doses or times examined (the example of 3,4ETBUT-NIT is given in Fig 5), whereas the hydrogen peroxide positive control gave a clear ROS response.

\section{Glutathione Determination}

The tripeptide glutathione helps to maintain redox homeostasis to protect cells from free radical damage. The depletion of reduced glutathione levels at early times of exposure to chemicals is one of the signs of cell stress (Circu and Aw 2008). Reduced glutathione was assessed using the OPA assay to determine the effect of treatment with glucosinolate hydrolysis products. The reaction of reduced glutathione and nonfluorescent OPA gives the fluorescent product glutathione-O-phthalaldehyde $(\mathrm{GSH}$ OPA) (Simons and Johnson 1978). Two of the compounds that exhibited toxicity, 2,3PROP-ITC and 3,4-ETBUT-NIT were used to treat CHo1 and MCL-5 cells and the reduced GSH levels were assessed.

Since 2,3-PROP-ITC induced toxicity, oxidative stress and inhibited cytochrome P450 enzyme activity, we hypothesized that the compound may deplete reduced glutathione levels. As shown in Figure 6, in MCL-5 cells treated with 2,3-PROP-ITC (10 $\mu \mathrm{M}$ and 100 

control, then levels decreased significantly after $4-8 \mathrm{~h}$ of exposure. After $24 \mathrm{~h}$ of exposure, the cellular GSH levels significantly increased presumably due to enhanced synthesis of GSH in response to the toxicity. A similar trend was observed in the $\mathrm{cHo}$ cells, although only the elevated levels of GSH observed after $24 \mathrm{~h}$ of treatment were significantly different from control.

As shown in Figure 6, treatment of cells with 3,4-ETBUT-NIT resulted in no significant alterations in GSH levels compared to vehicle control.

\section{Mitochondria Permeability}

Previous studies have shown that the isothiocyanates were able to inhibit mitochondrial trans-membrane potential $\left(\Delta \Psi_{\mathrm{m}}\right)$ in human bladder cancer UM-UC3 cells (Tang and Zhang 2005). We therefore examined the ability of the glucosinolate hydrolysis products used in the current study to affect mitochondrial membrane permeability in cHol and MCL-5 cells using loss of Rh123 fluorescence from pre-loaded cells.

Treatment with $\mathrm{H}_{2} \mathrm{O}_{2}$ (positive control) induced mitochondrial permeability that became increasingly pronounced from $8 \mathrm{~h}$ onwards (Fig 7). Although not significantly different from controls, similar effects were also be seen with high dose 2,3-PROP-ITC (100 $\mu \mathrm{M})$ in the cHo1 cell line but was less evident in the MCL-5 cell line and only became readily apparent at the $24 \mathrm{~h}$ time point. The effect was both dose and time dependent.

Treatment with 3,4-ETBUT-NIT, 3,4-BUT-NIT, 3,4-BUT-ITC, 4,5-ETPENT-NIT and 4,5PENT-NIT all failed to affect rhodamine loss in either cell type (data not shown).

\section{Cell cycle}

Previous literature has described the ability of ITCs to induce G2/M phase arrest (Smith et al. 2004). However, there are no reported effects of the ETNs and nitriles on cell cycle. Based on our cytotoxicity study, we hypothesised that ITCs and ETNs affect the cell cycle. Therefore, we examined the effect of treating $\mathrm{cHol}$ and MCL-5 cells with 2,3- 
PROP-ITC, 3,4-BUT-ITC, 3,4-ETBUT-NIT, 4,5-ETPENT-NIT, 3,4-BUT-NIT and 4,5PENT-NIT on cell cycle using propidium iodide (PI) intercalation with DNA and flow cytometry, (Zhu and Gooderham 2002).

\section{2,3-PROP-ITC}

In cHo1 cells treated with 2,3-PROP-ITC for $24 \mathrm{~h}$, there was a dose dependent increase in the sub G1 population. The sub G1 signal is indicative of cells undergoing cell death, primarily apoptotic cell death. This effect is more pronounced at $48 \mathrm{~h}$ (Fig 8). At $24 \mathrm{~h}$, the effect of 2,3-PROP-ITC treatment of cHo1 cells on the G1 population is marginal but at $48 \mathrm{~h}$ the $\mathrm{G} 1$ population was much lower, whereas there was a decrease in the $S$ phase population at $24 \mathrm{~h}$ but the effect was lost at $48 \mathrm{~h}$ (Fig 8). However the G2/M population was dose-dependently increased at $24 \mathrm{~h}$ (Fig 8 ) but the effect was lost at $48 \mathrm{~h}$.

With MCL-5 cells treated with 2,3-PROP-ITC for $24 \mathrm{~h}$, there was an increase in sub G1 population that was dose dependent and persistent up to $48 \mathrm{~h}$ (Fig 8). There was some reduction in the $\mathrm{G} 1$ and the $S$ phase populations, and a significant increase in the G2/M population at high concentration at $24 \mathrm{~h}$ (Fig 8). The effect on the sub-G1 population was more pronounced at $48 \mathrm{~h}$ after treatment as was the reduction in the $S$ phase population.

\section{3,4-ETBUT-NIT}

3,4-ETBUT-NIT treatment of $\mathrm{cHo} 1$ for $24 \mathrm{~h}$ showed little change in the different phase populations and there was little evidence of changes in cell death (sub G1) at this timepoint (Fig 9). By $48 \mathrm{~h}$ of treatment there was an increased sub $\mathrm{G} 1$ population but no evidence of change in the other phases. Similar changes were noted in the cell cycle of MCL-5 cells after 3,4-ETBUT-NIT treatment (Fig 9).

\section{3,4-BUT-ITC}

3,4-BUT-ITC treatment of $\mathrm{cHo} 1$ for up to $48 \mathrm{~h}$ induced an increase in the sub G1 peak with increasing dose (see Fig 9). This coincided with a dose-dependent decrease in the 
G1 population at $48 \mathrm{H}$. Neither the $\mathrm{S}$, nor the G2M populations appeared to be affected by the treatment. Treatment of MCL-5 cells with 3-BUTITC for up to $48 \mathrm{~h}$ did not induce dose-dependent significant effects on the cell cycle (Fig 9).

\title{
4,5-ETPENT-NIT, 3,4-BUT-NIT and 4,5-PENT-NIT
}

Treatment of $\mathrm{cHo} 1$ and MCL-5 cells with 4,5-ETPENT-NIT, 3,4-BUT-NIT and 4,5PENT-NIT for up to $48 \mathrm{~h}$ failed to alter the cell cycle populations (data not shown).

\begin{abstract}
Assessment of cell death by flow cytometry
Annexin $\mathrm{V}$ and propidium iodide $(\mathrm{PI})$ combination staining can be used to determine if the mechanism of cell death is through apoptosis or necrosis (Darzynkiewicz et al. 2001), (Zhu and Gooderham 2002). Based on the cell viability and cell cycle data, we chose to look further at 3 compounds (2,3-PROP-ITC, 3,4-BUT-ITC and 3,4-ETBUTNIT). Each of the three compounds were found to induce cell death in both $\mathrm{cHol}$ and MCL5 cells. 2,3-PROP-ITC and 3,4-BUT-ITC exposure $(100 \mu \mathrm{M})$ for $48 \mathrm{~h}$ induced a significant levels of necrotic cell death in both cHol and MCL5 cells (Fig 10). This necrosis effect was also observed for 3,4-ETBUT-NIT $(100 \mu \mathrm{M})$ treatment and there was a trend for an increased percentage of apoptotic cells ( 1.5 fold compared to control) in both cell types (Fig 10) .
\end{abstract}

\section{Discussion}

Glucosinolate hydrolysis products especially ITC are capable of inducing cell death. The cytotoxic effect of the glucosinolate hydrolysis products was thought to correspond to the effects on CYP enzyme activity and glutathione levels in the cells. Moreover, Wu et al., (Wu et al. 2005) reported that the potency of the apoptotic effect induced by ITC depends on the structure of the chemical as well as the cells that were used in the study. However, the glucosinolate hydrolysis products include not only ITCs but also ETNs and nitriles, thus we investigated the potential cell death induced by different types of glucosinolate hydrolysis products. We found that the glucosinolate hydrolysis products were cytotoxic to both MCL-5 (engineered to express CYP enzymes) and 
cHo1 (no engineered CYP expression) cells and that the role of metabolism was chemical-specific. It has been reported that Brassica vegetables were able to induce CYP1A2 activity (Lampe et al. 2000), and others (Conaway et al. 1996; La Marca et al. 2012) demonstrated that ITC were able to inhibit CYP enzymes $1 A 1$ and $1 A 2$. These findings suggest a mechanism whereby ITC inhibition of CYP is followed by compensation leading to CYP induction. More relevant to the present study, La Marcia et al. (La Marca et al. 2012) reported that 2,3-PROP-ITC and 3,4-BUT-ITC failed to inhibit EROD at $40 \mu \mathrm{M}$. Consistent with this, in our investigation 2,3-PROP-ITC and 3,4-BUT-ITC only showed a significant inhibition of CYP1A activity at the highest dose used $(100 \mu \mathrm{M})$ in our ITC/ethoxyresorufin co-incubation experiments. However, it is important to note that at these high concentrations both 2,3-PROP-ITC and 3,4-BUTITC are cytotoxic and the CYP inhibition is therefore confounded by this toxicity. We therefore explored this further by examining EROD activity in MCL- 5 cells that had been pretreated with sub-cytotoxic doses of 2,3-PROP-ITC $(0-2 \mu \mathrm{M})$ for $24 \mathrm{~h}$. Under these conditions, 2,3-PROP-ITC significantly inhibited EROD in a dose-dependent manner, but failed to alter CYP1A1 gene expression. These observations suggest that treatment with sub-cytotoxic doses of 2,3-PROP-ITC impairs CYP1A1 enzyme activity but does not alter gene expression within the $24 \mathrm{~h}$ treatment time period. A downstream consequence of this enzyme impairment could result in electron uncoupling which may lead to the oxidative stress noted here. In contrast, under the same experimental conditions, sub-cytotoxic doses of 3,4-BUT-ITC failed to inhibit EROD, suggesting that the effects noted with high dose 3,4-BUT-ITC treatment were related to cytotoxicity.

Reactive oxygen species (ROS) are mediators of intracellular signalling cascades and excessive production of ROS may lead to oxidative stress, which can promote apoptosis or necrosis (Singh et al. 2005) (Wu et al. 2005). Our results have shown that 2,3-PROP-ITC was able to induce reactive oxygen species in MCL-5 cells. The other glucosinolate hydrolysis compounds we examined had only marginal effect on ROS production. Reactive oxygen species are capable of damaging key biological molecules in the cell and this is prevented by reaction with nucleophilic glutathione (GSH)(Loo 2003). In addition, all ITC are characterised with a functional group $(\mathrm{N}=\mathrm{C}=\mathrm{S})$ that is 
highly electrophilic because of their central carbon. This electrophilic group may react with nitrogen-, oxygen- and sulphur-based nucleophiles, including GSH to form thiourea derivatives, thiocarbamates and dithiocarbamates, respectively.

We therefore investigated whether the oxidative stress noted here may affect GSH level after the glucosinolate hydrolysis products were exposed to the cells. Our results show that GSH levels in MCL-5 cells were decreased at $4 \mathrm{~h}$ to $8 \mathrm{~h}$ with 2,3-PROP-ITC (10 $\mu \mathrm{M}$ and $100 \mu \mathrm{M}$ ) exposure. Interestingly, after $8 \mathrm{~h}$ of the treatment, the GSH level gradually increased in both cell lines, consistent with GSH synthesis due to the increased cellular requirement. With 2,3-PROP-ITC, which is highly electrophilic and easily reacts with nucleophiles such as the - $\mathrm{SH}$ group in GSH structure, the decrease in GSH levels was likely due to ITC conjugation. When cells are redox imbalanced after exposure to reactive electrophilic chemicals, there is a decline in GSH levels and promotion of ROS production further contributing to GSH decline and a concomitant induction of cell death.

In theory, ROS and subsequent lipid peroxide production in mitochondria can affect mitochondrial functions such respiration and oxidative phosphorylation, inner membrane barrier properties, maintenance of mitochondrial membrane potential $\left(\Delta \Psi_{\mathrm{m}}\right)$ and mitochondrial $\mathrm{Ca}^{2+}$ buffering capacity (Zhang et al. 1990) (Bellomo et al. 1991) (Ott et al. 2007). The excessive production of ROS could potentially stimulate $\mathrm{Ca}^{2+}$ relocalisation which may cause the opening of the permeability transition pore (PTP) and lead to cell death (Ott et al. 2007). This mechanism could be one of the contributors to cell death noted in the present study. Our analysis showed an increase of rhodamine fluorescence at $30 \mathrm{~min}$ followed by a trend for the loss of mitochondrial trans-membrane potential at $6 \mathrm{~h}$ to $24 \mathrm{~h}$ after 2,3-PROP-ITC (10 uM and $100 \mathrm{uM}$ ) exposure, however these changes were not significantly different from the controls. This suggests a potential loss of mitochondrial transmembrane potential, $(\Delta \Psi \mathrm{m})$ leading to cell death (Zamzami and Kroemer 2001); (Tang and Zhang 2004). The other compounds showed very little effect on the mitochondrial membrane potential $\left(\Delta \psi_{\mathrm{m}}\right)$. 

HT29 (Lund et al., 2001), GBM 8401 (Chen et al. 2010) and PC-3 cells (Xiao et al. 2003). Our results have shown that the exposure of 2,3-PROP-ITC (100 uM) for 24 and $48 \mathrm{~h}$ to $\mathrm{CHo} 1$ and MCL-5 cells induced an increase of the G2/M phase population and similar trend was observed in the cells that were treated with 3,4-BUT-ITC. Thus these two glucosinolate hydrolysis compounds were able to inhibit cell proliferation and arrest the cell cycle. On the other hand, 3,4-ETBUT-NIT treatment was also seen to be cytotoxic but showed cell cycle arrest at G1 phase rather than G2/M. This G1 arrest suggests mechanisms of cytotoxicity differ between the ITCs and ETNs.

Apoptosis induced by 2,3-PROP-ITC has been described (Chen et al. 2010), (Tang and Zhang 2005). Xiao et al.,(Xiao et al. 2003) postulated that 2,3-PROP-ITC induced apoptosis in prostate cancer cells, PC-3 and LNCaP, through cell cycle arrest by reducing activity of Cdk1/cyclin B kinase complex and down-regulation of G2/M regulating proteins. Tang and Zhang, (Tang and Zhang 2005) found that 2,3-PROP-ITC caused mitochondria membrane damage (inner and outer membrane) in human bladder cancer, promoting release of cytochrome $c$ into cytoplasm which triggers caspase- 9 and apoptosis induction. Mitotic arrest was reported to be induced by 2,3-PROP-ITC along with mitochondria-mediated apoptosis through release of cytochrome $\mathrm{c}$, which triggers caspase-9 and caspase-3 (Geng et al. 2011) (Tang and Zhang 2005). Although, a lot of studies have proposed that 2,3-PROP-ITC induces apoptosis, others suggest that this is not a mechanism of ITC mediated cell death (Smith et al. 2004). Our results indicate that 2,3-PROP-ITC, 3,4-BUT-ITC and 3,4-ETBUT-NIT caused cell death predominantly via necrosis and additionally 3,4-ETBUT-NIT induces apoptosis.

The question arises as to what extent ETNs are present in the human diet and what if any beneficial effects they have. It has been shown that in some cabbages that 3,4ETBUT-NIT is the dominant product (Kyung et al. 1995) and we have shown that this is also true for two commonly available cabbages in the UK, Sweetheart and Savoy. Analysis showed that 3,4-ETBUT-NIT was the dominant product giving values of 2.31 $\mu \mathrm{mol} \pm 0.84$ and $24.77 \mu \mathrm{mol} \pm 1.84 / 100 \mathrm{~g}$ fresh weight for Sweetheart and Savoy 
respectively (Abd Kadir 2013). 2,3-PROP-ITC and 3,4-BUT-NIT were not detected. Thus it would seem that ETNs are likely consumed as part of the diet where raw Brassica vegetables are eaten. The dose would potentially be comparable to ITCs assuming that ETNs are readily produced during eating. Thus more work is required, particularly human studies where ETN metabolism can be monitored and the types of metabolite determined.

In summary, in attempting to understand the putative chemopreventative properties of the cruciferous vegetables, we have explored the cellular toxicity of glucosinolate hydrolysis products and confirm that toxicity is predominantly associated with the ITCs and to a lesser extent the ETNs. Our data also suggest that the mechanisms of cell death are different between the two chemical groups and this finding merits further investigation. 


\section{Acknowledgements}

N.H.A.K. was funded by a scholarship from the Malaysian Government. N.J.G. acknowledges funding from the UK Food Standards Agency.

\section{Conflict of Interest.}

The authors have no conflicts of interest to declare. 


\section{References}

Abbaoui B, Riedl KM, Ralston RA, et al. (2012) Inhibition of bladder cancer by broccoli isothiocyanates sulforaphane and erucin: Characterization, metabolism, and interconversion. Molecular Nutrition \& Food Research 56(11):1675-1687 doi:10.1002/mnfr.201200276

Abd Kadir NH (2013) Cytotoxicity of 2-Propenyl and 3-butenylglucosinolate hydrolysis products in cHo1 and MCL-5 Cell Lines. PhD Thesis, Imperial College London

Bellomo G, Fulceri R, Albano E, et al. (1991) Ca(2+)-dependent and independent mitochondrial damage in hepatocellular injury. Cell calcium 12(5):335-41

Bones AM, Rossiter JT (1996) The myrosinase-glucosinolate system, its organisation and biochemistry. Physiologia Plantarum 97(1):194-208 doi:10.1034/j.1399-3054.1996.970128.x

Bones AM, Rossiter JT (2006) The enzymic and chemically induced decomposition of glucosinolates. Phytochemistry 67(11):1053-67 doi:10.1016/j.phytochem.2006.02.024

Brocker ER, Benn MH, Luthy J, Vondaniken A (1984) METABOLISM AND DISTRIBUTION OF 3,4EPITHIOBUTANENITRILE IN THE RAT. Food and Chemical Toxicology 22(3):227-232 doi:10.1016/0278-6915(84)90132-7

Chen NG, Chen KT, Lu CC, et al. (2010) Allyl isothiocyanate triggers G2/M phase arrest and apoptosis in human brain malignant glioma GBM 8401 cells through a mitochondria-dependent pathway. Oncology reports 24(2):449-55

Circu ML, Aw TY (2008) Glutathione and apoptosis. Free radical research 42(8):689-706 doi:10.1080/10715760802317663

Conaway CC, Jiao D, Chung FL (1996) Inhibition of rat liver cytochrome P450 isozymes by isothiocyanates and their conjugates: a structure-activity relationship study. Carcinogenesis 17(11):2423-7

Crespi CL (1991) Expression of cytochrome P450 cDNAs in human B lymphoblastoid cells: applications to toxicology and metabolite analysis. Methods in enzymology 206:123-9

Darzynkiewicz Z, Li X, Bedner E (2001) Use of flow and laser-scanning cytometry in analysis of cell death. Methods in cell biology 66:69-109

Druckrey H, Kruse H, Preussma.R, Ivankovi.S, Landschu.C (1970) CANCEROGENIC ALKYLATING SUBSTANCES .3. ALKYL-HALOGENIDES, ALKYL-SULFATES, ALKYL-SULFONATES AND STRAINED HETEROCYCLIC COMPOUNDS. Zeitschrift Fur Krebsforschung 74(3):241-\& doi:10.1007/bf00525457

Ellinger MaH, JE (1955) The mustard oil of rape seed allylcarbinyl isothiocyanate and synthetic isomers. Journal of the American Chemical Society 77:1831 - 1836

Fahey JW, Wehage SL, Holtzclaw WD, et al. (2012) Protection of Humans by Plant Glucosinolates: Efficiency of Conversion of Glucosinolates to Isothiocyanates by the Gastrointestinal Microflora. Cancer Prevention Research 5(4):603-611 doi:10.1158/1940-6207.capr-11-0538

Feskanich D, Ziegler RG, Michaud DS, et al. (2000) Prospective study of fruit and vegetable consumption and risk of lung cancer among men and women. Journal of the National Cancer Institute 92(22):1812-23

Geng F, Tang L, Li Y, et al. (2011) Allyl isothiocyanate arrests cancer cells in mitosis, and mitotic arrest in turn leads to apoptosis via $\mathrm{Bcl}-2$ protein phosphorylation. The Journal of biological chemistry 286(37):32259-67 doi:10.1074/jbc.M111.278127

Gribkov DV, Hultzsch KC, Hampel F (2006) 3,3 '-bis(trisarylsilyl)-substituted binaphtholate rare earth metal catalysts for asymmetric hydroamination. Journal of the American Chemical Society 128(11):3748-3759 doi:10.1021/ja058287t

Gupta P, Kim B, Kim S-H, Srivastava SK (2014) Molecular targets of isothiocyanates in cancer: Recent advances. Molecular Nutrition \& Food Research 58(8):1685-1707 doi:10.1002/mnfr.201300684 
Hanschen FS, Lamy E, Schreiner M, Rohn S (2014) Reactivity and Stability of Glucosinolates and Their Breakdown Products in Foods. Angewandte Chemie-International Edition 53(43):11430-11450 doi:10.1002/anie.201402639

Hayes JD, Kelleher MO, Eggleston IM (2008) The cancer chemopreventive actions of phytochemicals derived from glucosinolates. European journal of nutrition 47 Suppl 2:73-88 doi:10.1007/s00394-008-2009-8

Hissin PJ, Hilf R (1976) A fluorometric method for determination of oxidized and reduced glutathione in tissues. Analytical biochemistry 74(1):214-26

Hummerich J, Zohm C, Pfau W (2004) Modulation of cytochrome P450 1A1 by food-derived heterocyclic aromatic amines. Toxicology 199(2-3):231-40 doi:10.1016/j.tox.2004.02.028

Kelleher MO, McMahon M, Eggleston IM, et al. (2009) 1-Cyano-2,3-epithiopropane is a novel plantderived chemopreventive agent which induces cytoprotective genes that afford resistance against the genotoxic alpha,beta-unsaturated aldehyde acrolein. Carcinogenesis 30(10):17541762 doi:10.1093/carcin/bgp182

Kyung KH, Fleming HP, Young CT, Haney CA (1995) 1-CYANO-2,3-EPITHIOPROPANE AS THE PRIMARY SINIGRIN HYDROLYSIS PRODUCT OF FRESH CABBAGE. Journal of Food Science 60(1):157-159 doi:10.1111/j.1365-2621.1995.tb05628.x

La Marca M, Beffy P, Della Croce C, et al. (2012) Structural influence of isothiocyanates on expression of cytochrome P450, phase II enzymes, and activation of Nrf2 in primary rat hepatocytes. Food and chemical toxicology : an international journal published for the British Industrial Biological Research Association 50(8):2822-30 doi:10.1016/j.fct.2012.05.044

Lampe JW, King IB, Li S, et al. (2000) Brassica vegetables increase and apiaceous vegetables decrease cytochrome P450 1A2 activity in humans: changes in caffeine metabolite ratios in response to controlled vegetable diets. Carcinogenesis 21(6):1157-62

Livak KJ, Schmittgen TD (2001) Analysis of relative gene expression data using real-time quantitative PCR and the 2(-Delta Delta C(T)) Method. Methods 25(4):402-8 doi:10.1006/meth.2001.1262

Loo G (2003) Redox-sensitive mechanisms of phytochemical-mediated inhibition of cancer cell proliferation (review). The Journal of nutritional biochemistry 14(2):64-73

Luang-In V, Narbad A, Nueno-Palop C, Mithen R, Bennett M, Rossiter JT (2014) The metabolism of methylsulfinylalkyl- and methylthioalkyl- glucosinolates by a selection of human gut bacteria. Molecular Nutrition \& Food Research 58(4):875-883 doi:10.1002/mnfr.201300377

Luethy J, Von Daeniken A, Friederich U, et al. (1980) SYNTHESIS AND TOXICOLOGY OF 3 NATURALLY OCCURRING CYANO EPI THIO ALKANES. International Journal for Vitamin and Nutrition Research 50(4):423-424

Luthy J, Benn M (1980) CYANO EPI THIO ALKANES SOME CHEMICAL AND TOXICOLOGICAL STUDIES,

Luthy J, Vondaniken A, Friederich U, et al. (1980) SYNTHESIS AND TOXICOLOGY OF 3 NATURAL CYANOEPITHIOALKANES. International Journal for Vitamin and Nutrition Research 50(4):423-424

Munday R, Zhang Y, Munday CM, Bapardekar MV, Paonessa JD (2008) Structure-Activity Relationships and Organ Specificity in the Induction of GST and NQO1 by Alkyl-Aryl Isothiocyanates. Pharmaceutical Research 25(9):2164-2170 doi:10.1007/s11095-008-9595-2

Nakamura Y, Miyoshi N (2010) Electrophiles in Foods: The Current Status of Isothiocyanates and Their Chemical Biology. Bioscience Biotechnology and Biochemistry 74(2):242-255 doi:10.1271/bbb.90731

Nishie K, Daxenbichler ME (1980) TOXICOLOGY OF GLUCOSINOLATES, RELATED-COMPOUNDS (NITRILES, R-GOITRIN, ISOTHIOCYANATES) AND VITAMIN-U FOUND IN CRUCIFERAE. Food and Cosmetics Toxicology 18(2):159-\& doi:10.1016/0015-6264(80)90070-x 
Ott M, Gogvadze V, Orrenius S, Zhivotovsky B (2007) Mitochondria, oxidative stress and cell death. Apoptosis : an international journal on programmed cell death 12(5):913-22 doi:10.1007/s10495-007-0756-2

Piberger AL, Koeberle B, Hartwig A (2014) The broccoli-born isothiocyanate sulforaphane impairs nucleotide excision repair: XPA as one potential target. Archives of Toxicology 88(3):647-658 doi:10.1007/s00204-013-1178-2

Saha S, Hollands W, Teucher B, et al. (2012) Isothiocyanate concentrations and interconversion of sulforaphane to erucin in human subjects after consumption of commercial frozen broccoli compared to fresh broccoli. Molecular Nutrition \& Food Research 56(12):1906-1916 doi:10.1002/mnfr.201200225

Said T, Dutot M, Christon R, et al. (2007) Benefits and side effects of different vegetable oil vectors on apoptosis, oxidative stress, and P2X7 cell death receptor activation. Investigative ophthalmology \& visual science 48(11):5000-6 doi:10.1167/iovs.07-0229

Sarikamis G, Marquez J, MacCormack R, Bennett RN, Roberts J, Mithen R (2006) High glucosinolate broccoli: a delivery system for sulforaphane. Molecular Breeding 18(3):219-228 doi:10.1007/s11032-006-9029-y

Shao J, White CC, Dabrowski MJ, Kavanagh TJ, Eckert ML, Gallagher EP (2008) The role of mitochondrial and oxidative injury in BDE 47 toxicity to human fetal liver hematopoietic stem cells. Toxicological sciences : an official journal of the Society of Toxicology 101(1):81-90 doi:10.1093/toxsci/kfm256

Simons SS, Jr., Johnson DF (1978) Reaction of o-phthalaldehyde and thiols with primary amines: fluorescence properties of 1-alkyl(and aryl)thio-2-alkylisoindoles. Analytical biochemistry 90(2):705-25

Singh AV, Xiao D, Lew KL, Dhir R, Singh SV (2004) Sulforaphane induces caspase-mediated apoptosis in cultured PC-3 human prostate cancer cells and retards growth of PC-3 xenografts in vivo. Carcinogenesis 25(1):83-90 doi:10.1093/carcin/bgg178

Singh SV, Srivastava SK, Choi S, et al. (2005) Sulforaphane-induced cell death in human prostate cancer cells is initiated by reactive oxygen species. The Journal of biological chemistry 280(20):1991124 doi:10.1074/jbc.M412443200

Smith TJ, Yang CS (2000) Effect of organosulfur compounds from garlic and cruciferous vegetables on drug metabolism enzymes. Drug metabolism and drug interactions 17(1-4):23-49

Smith TK, Lund EK, Parker ML, Clarke RG, Johnson IT (2004) Allyl-isothiocyanate causes mitotic block, loss of cell adhesion and disrupted cytoskeletal structure in HT29 cells. Carcinogenesis 25(8):1409-15 doi:10.1093/carcin/bgh149

Tang L, Zhang Y (2004) Dietary isothiocyanates inhibit the growth of human bladder carcinoma cells. The Journal of nutrition 134(8):2004-10

Tang L, Zhang Y (2005) Mitochondria are the primary target in isothiocyanate-induced apoptosis in human bladder cancer cells. Molecular cancer therapeutics 4(8):1250-9 doi:10.1158/15357163.MCT-05-0041

Tramontina F, Karl J, Gottfried C, et al. (2000) Digitonin-permeabilization of astrocytes in culture monitored by trypan blue exclusion and loss of S100B by ELISA. Brain research Brain research protocols 6(1-2):86-90

Uda $Y$, Ohnuki $H$, Matsuzawa M (1992) MUTAGENICITY OF VOLATILE OMEGA-ALKENYL ISOTHIOCYANATES AND THEIR CORRESPONDING CYANOEPITHIOALKANES. Bioscience Biotechnology and Biochemistry 56(1):159-160 doi:10.1271/bbb.56.159

Voorrips LE, Goldbohm RA, van Poppel G, Sturmans F, Hermus RJ, van den Brandt PA (2000) Vegetable and fruit consumption and risks of colon and rectal cancer in a prospective cohort study: The 
Netherlands Cohort Study on Diet and Cancer. American journal of epidemiology 152(11):108192

Willett WC (2000) Diet and cancer. The oncologist 5(5):393-404

Wu X, Kassie F, Mersch-Sundermann V (2005) Induction of apoptosis in tumor cells by naturally occurring sulfur-containing compounds. Mutation research 589(2):81-102 doi:10.1016/j.mrrev.2004.11.001

Xiao D, Srivastava SK, Lew KL, et al. (2003) Allyl isothiocyanate, a constituent of cruciferous vegetables, inhibits proliferation of human prostate cancer cells by causing $\mathrm{G} 2 / \mathrm{M}$ arrest and inducing apoptosis. Carcinogenesis 24(5):891-7

Xu K, Thornalley PJ (2000) Studies on the mechanism of the inhibition of human leukaemia cell growth by dietary isothiocyanates and their cysteine adducts in vitro. Biochemical pharmacology 60(2):221-31

Zamzami N, Kroemer G (2001) The mitochondrion in apoptosis: how Pandora's box opens. Nature reviews Molecular cell biology 2(1):67-71 doi:10.1038/35048073

Zhang Y, Marcillat O, Giulivi C, Ernster L, Davies KJ (1990) The oxidative inactivation of mitochondrial electron transport chain components and ATPase. The Journal of biological chemistry 265(27):16330-6

Zhang Y, Talalay $P$ (1994) Anticarcinogenic activities of organic isothiocyanates: chemistry and mechanisms. Cancer Res 54(7 Suppl):1976s-1981s

Zhao B, Seow A, Lee EJ, et al. (2001) Dietary isothiocyanates, glutathione S-transferase -M1, -T1 polymorphisms and lung cancer risk among Chinese women in Singapore. Cancer epidemiology, biomarkers \& prevention : a publication of the American Association for Cancer Research, cosponsored by the American Society of Preventive Oncology 10(10):1063-7

Zhu H, Gooderham N (2002) Neoplastic transformation of human lung fibroblast MRC-5 SV2 cells induced by benzo[a]pyrene and confluence culture. Cancer Res 62(16):4605-9 
Table 1: Cytotoxicity of glucosinolate hydrolysis products after $48 \mathrm{~h}$ of treatment.

\begin{tabular}{|c|c|c|}
\hline $\begin{array}{l}\text { Glucosinolate hydrolysis } \\
\text { products }\end{array}$ & $\begin{array}{c}\mathrm{EC}_{50} \text { in } \mathrm{cHo1} \\
(\mu \mathrm{M})\end{array}$ & $\begin{array}{c}E C_{50} \text { in MCL } 5 \\
(\mu \mathrm{M})\end{array}$ \\
\hline $\begin{array}{l}\text { 2-propenylisothiocyanate } \\
\text { (2,3-PROP-ITC) }\end{array}$ & 35.8 & 18.2 \\
\hline $\begin{array}{l}\text { 3-butenylisothiocyanate } \\
\text { (3,4-BUT-ITC) }\end{array}$ & $>100$ & $>100$ \\
\hline $\begin{array}{l}\text { 3,4-epithiobutylnitrile } \\
\text { (3,4-ETBUT-NIT) }\end{array}$ & 31.0 & 25.0 \\
\hline $\begin{array}{l}\text { 4,5-epithiopentylnitrile } \\
\text { (4,5-ETPENT-NIT) }\end{array}$ & 38.6 & 61.6 \\
\hline $\begin{array}{l}\text { 3-butenylnitrile } \\
\text { (3,4-BUT-NIT) }\end{array}$ & $>100$ & $>100$ \\
\hline $\begin{array}{l}\text { 4-pentenylnitrile } \\
\text { (4,5-PENT-NIT) }\end{array}$ & $>100$ & $>100$ \\
\hline
\end{tabular}


Figure legends

Figure 1: Structures of the glucosinolate hydrolysis products used in this study, (1) 2,3propenylisothiocyanate (2,3-PROP-ITC); (2) 3,4-butenylnitrile (3,4-BUT-NIT); (3) 3,4epithiobutylnitrile (3,4-ETBUT-NIT); (4) 3-butenylisothiocyanate (3,4-BUT-ITC); (5) 4pentenyInitrile (4,5-PENT-NIT); (6) 4,5-epithiopentyInitrile (4,5-ETPENT-NIT).

Figure 2: Effect of treatment of a) $\mathrm{CHo} 1 \mathrm{~b}$ ) MCL 5 cells with the glucosinolate hydrolysis products on cell viability at $48 \mathrm{~h}$ as assessed by AlamarBlue $\AA$ assay. Results are shown as percentage of vehicle control cell viability and are displayed as mean \pm SD for independent cultures $(n=4)$.

Figure 3: Ethoxyresorufin O-deethylase activity in MCL5 cells exposed to A) 3,4-BUTITC, B) 2,3-PROP-ITC, C) 3,4-ETBUT-NIT, D) 4,5-ETPENT-NIT, E) 3,4-BUT-NIT and F) 4,5 -PENT-NIT. Values are $\%$ of the control (mean \pm SEM of independent cultures, $\mathrm{n}=3$ ). One way ANOVA (Dunnet's post test) analysis was performed. ${ }^{* *} \mathrm{P}<0.01$, ${ }^{* * *} \mathrm{P}<0.001$.

Figure 4: Ethoxyresorufin O-deethylase activity in MCL5 cells pretreated for $24 \mathrm{~h}$ with $\mathrm{A}$ ) 3,4-BUT-ITC and B) 2,3-PROP-ITC. CYP1A1 mRNA expression in MCL5 cells pretreated for $24 \mathrm{~h}$ with C) 2,3-PROP-ITC. Values are $\%$ of the control (mean $\pm \mathrm{SEM}$ of independent cultures, $n=3$ ). One way ANOVA (Dunnet's post test) analysis was performed. ${ }^{*} \mathrm{P}<0.05$. A significant trend is shown in $B$ ) $p$-trend $<0.05$.

Figure 5: Induction of reactive oxygen species (ROS) by treatment of cells with glucosinolate hydrolysis products.

A, C (cHo1 cells) and B, D (MCL-5 cells) treated with A, B 2,3-PROP-ITC; C, D 3,4ETBUT-NIT. Values are mean \pm SEM for independent cultures $(n=4)$. Two way ANOVA (Benferroni post-test) analysis was performed. ${ }^{* *} \mathrm{P}<0.01,{ }^{* * *} \mathrm{P}<0.001$.

Figure 6: Dose and temporal effects of 2,3-PROP-ITC (A and B) and 3,4-ETBUT-NIT (C and $D$ ) on reduced glutathione levels in cHo1 ( $A$ and $C$ ) and MCL 5 (B and $D)$ cells. Values are means \pm SE of independent cultures $(n=3)$. One way ANOVA analysis (Dunnet test) was performed. ${ }^{* *}$ indicates $\mathrm{P}<0.01$ and ${ }^{* * *}$ indicates $\mathrm{P}<0.001$ significant difference between vehicle control and treatment.

Figure 7: Mitochondrial transmembrane potential measured by loss of Rhodamine 123 (Rh123) in A) cHo1 cells and B) MCL5 cells after treatment with 2,3-PROP-ITC. Values are mean \pm SEM for independent cultures $(n=3)$. ${ }^{*} P<0.05,{ }^{* *} P<0.01,{ }^{* * *} P<0.001$ compared to vehicle control.

Figure 8: Effect of 2,3-PROP-ITC on the cell cycle distribution of A) cHo1 cells and B) MCL5 cells after $24 \mathrm{~h}$ and $48 \mathrm{~h}$ treatment. Cell cycle profile after treatment with 2,3PROP-ITC in cHo1 cells for 24 (Aa) and 48 (Ab) hours and in MCL5 cells for 24 (Ba) and $48(\mathrm{Bb})$ hours. Values are mean \pm SEM for independent cultures $(n=3)$ analysed by 
FlowJo version 7.6.4. ${ }^{*} \mathrm{P}<0.05,{ }^{* *} \mathrm{P}<0.01,{ }^{* * *} \mathrm{P}<0.001$ significantly different from respective control (ANOVA).

Figure 9: Cell cycle profile of $\mathrm{cHo1}(\mathrm{A}, \mathrm{C}, \mathrm{E}$ and $\mathrm{G})$ and $\mathrm{MCL} 5(\mathrm{~B}, \mathrm{D}, \mathrm{F}$ and $\mathrm{H})$ cell populations after treatment with 3,4-ETBUT-NIT for 24 (A and B) and 48 (C and D) hours or with 3,4-BUT-ITC for 24 (E and F) or $48(G$ and $H)$ hours. Values are mean \pm SEM for independent cultures $(n=3)$ analysed by FlowJo version 7.6.4. ${ }^{*} P<0.05$, ${ }^{\star *} \mathrm{P}<0.01,{ }^{* \star} \mathrm{P}<0.001$ significantly different from respective control (ANOVA).

Figure 10: Flow cytometry analysis of annexin $\mathrm{V}$ and $\mathrm{PI}$ staining profile of $\mathrm{cHo} 1(\mathrm{~A})$ and MCL 5 (B) cells after treatment with 2,3-PROP-ITC, 3,4-BUT-ITC and 3,4-ETBUT-NIT. Q1 and Q2 show cells with increased PI staining (indicative of necrotic cells), Q3 and Q2 shows increased annexin V staining (indicative of apoptotic cells). Cells appearing in Q2 are likely to be a late apoptotic population. The proportions of $\mathrm{cHo} 1$ cells that are alive $(A a)$, apoptotic $(A b)$ or necrotic $(A c)$ or of MCL5 cells that are alive $(B a)$, apoptotic $(\mathrm{Bb})$ or necrotic $(\mathrm{Bc})$ after $48 \mathrm{~h}$ of treatment are shown. Values are mean \pm SEM for independent cultures $(n=3)$ analysed by FlowJo version 7.6.4. ${ }^{*} P<0.05,{ }^{* *} P<0.01$, ${ }^{* * *} \mathrm{P}<0.001$ significantly different from respective control (ANOVA). 


\section{Figure 1}

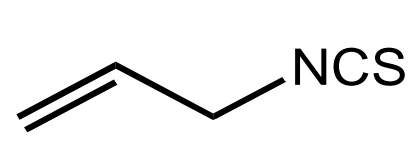

1

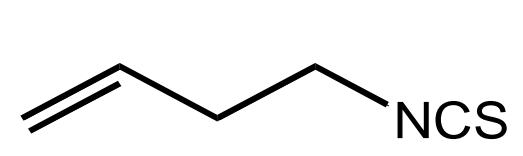

4

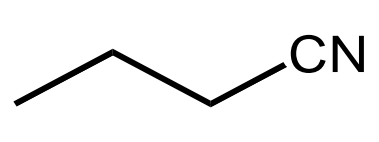

2

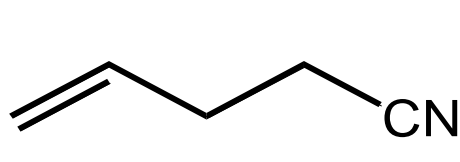

5

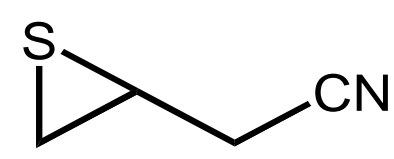

3<smiles>N#CCCC1CS1</smiles>

6 
Click here to download Figure: HudaR NJG figure 2.pptx

Figure 2
A

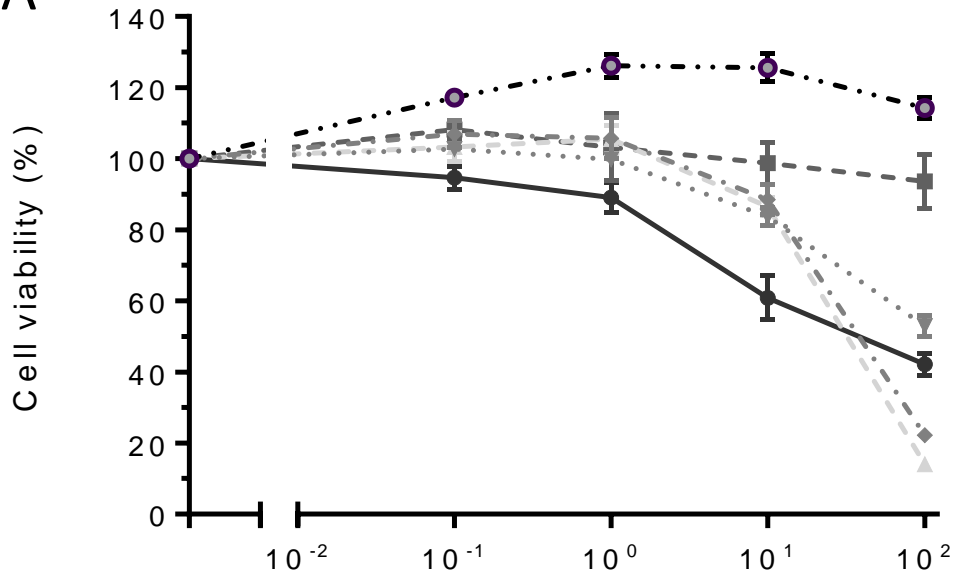

Concentration $(\mu \mathrm{M})$

B

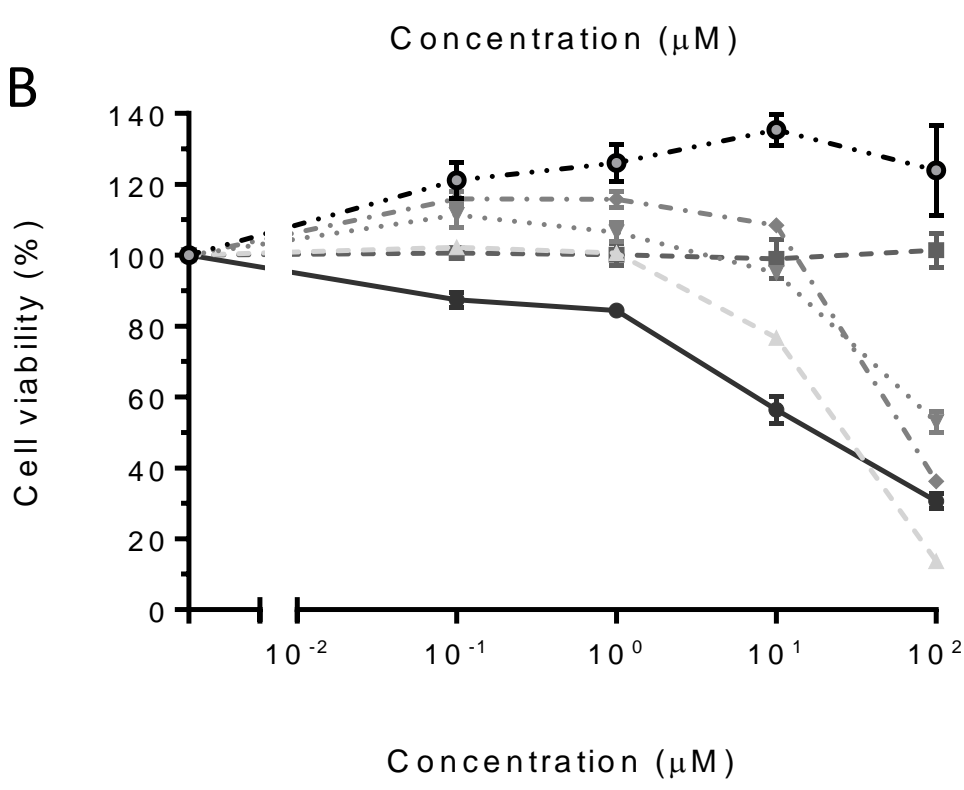

Concentration $(\mu \mathrm{M})$
-0. 4,5-PENT-NIT

$-\diamond$ 4,5-ETPENT-NIT

‥ 3,4-BUT-ITC

- $3,4-E T B U T-N I T$

- - $3,4-B \cup T-N I T$

$\rightarrow$ 2,3-PROP-ITC 


\section{Figure 3}
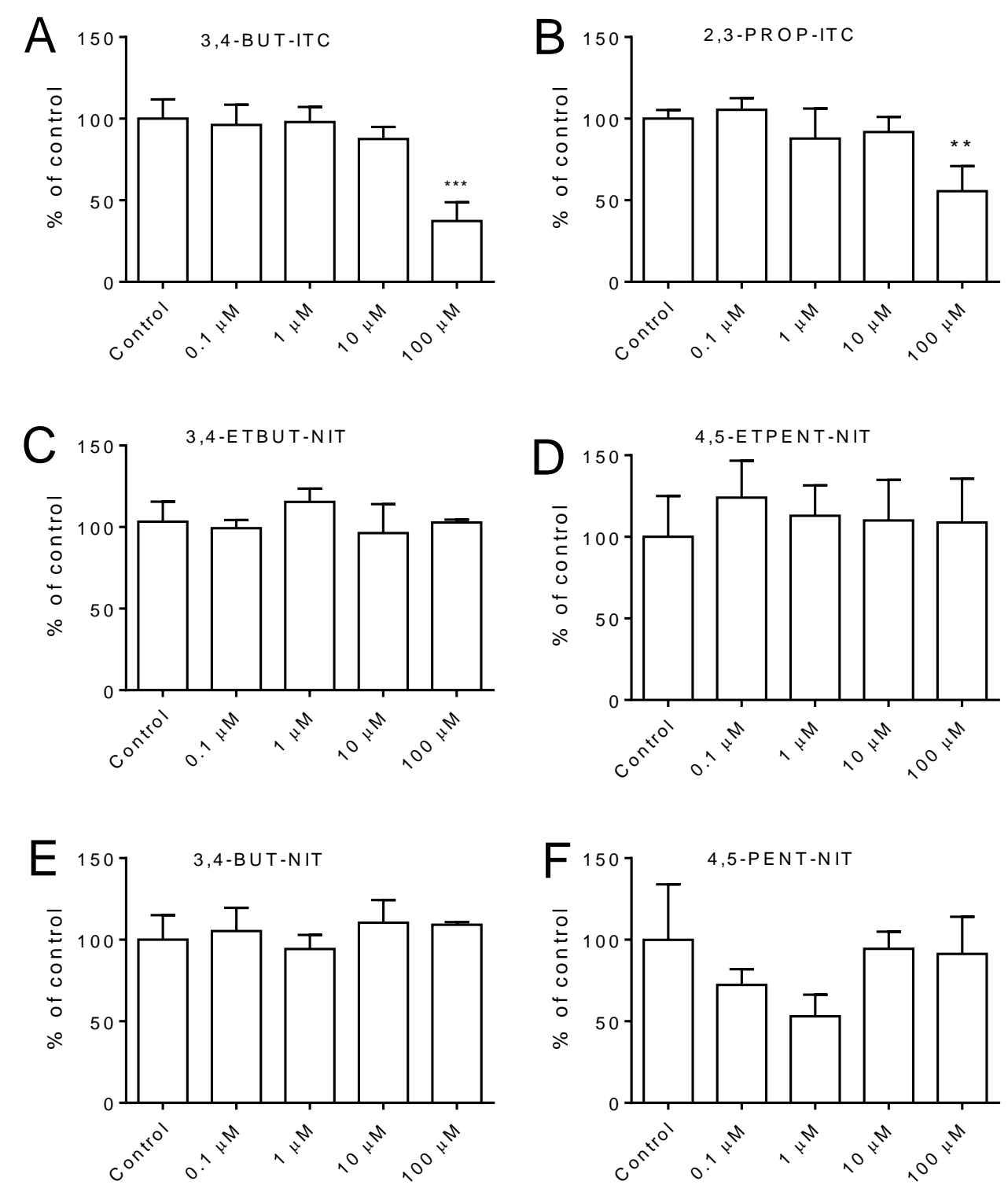
Figure 4

A

$$
\text { 3,4-BUT-ITC }
$$

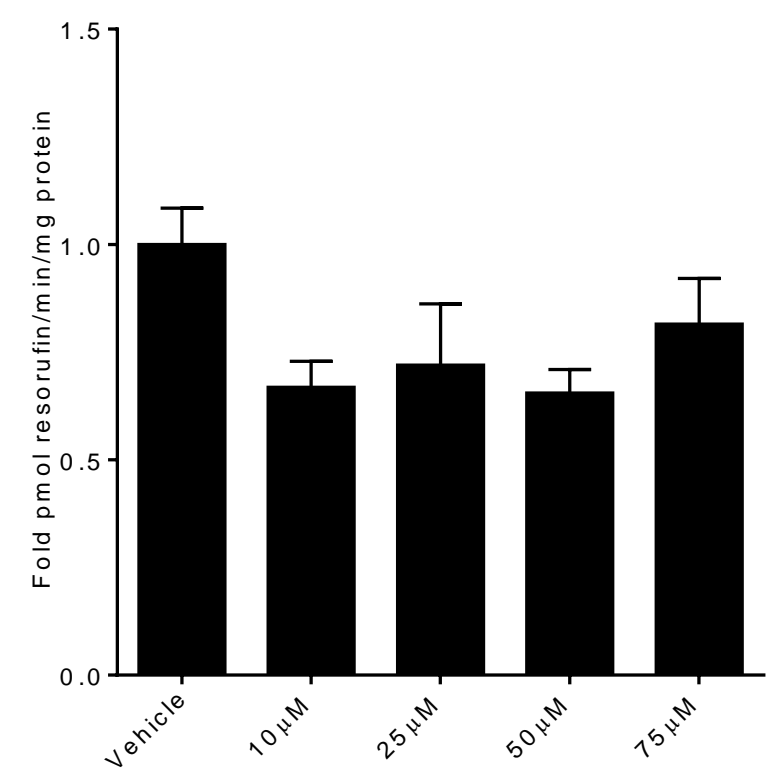

B

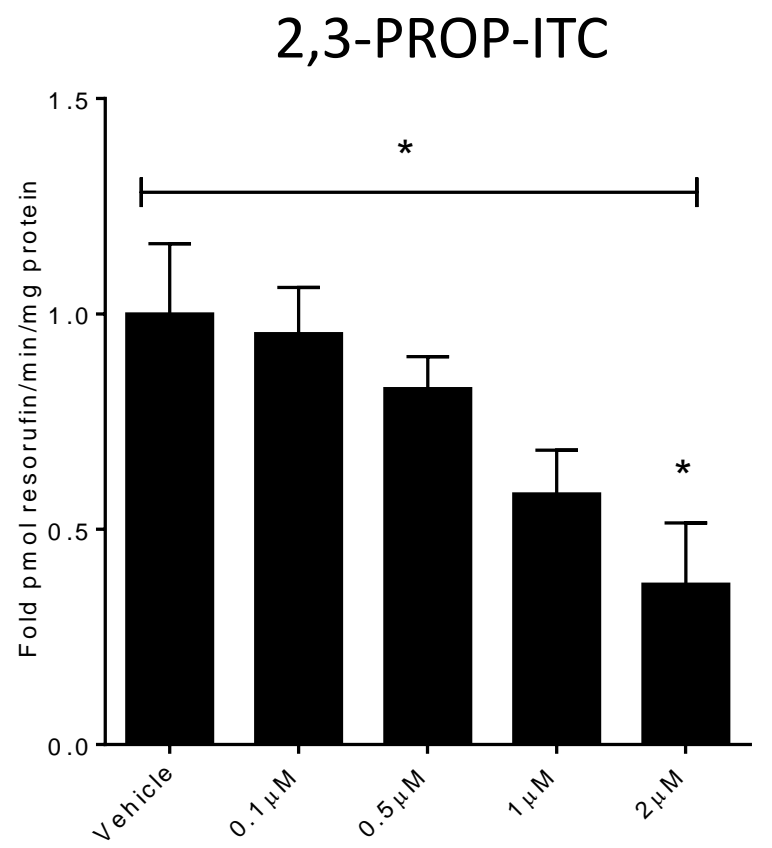

C

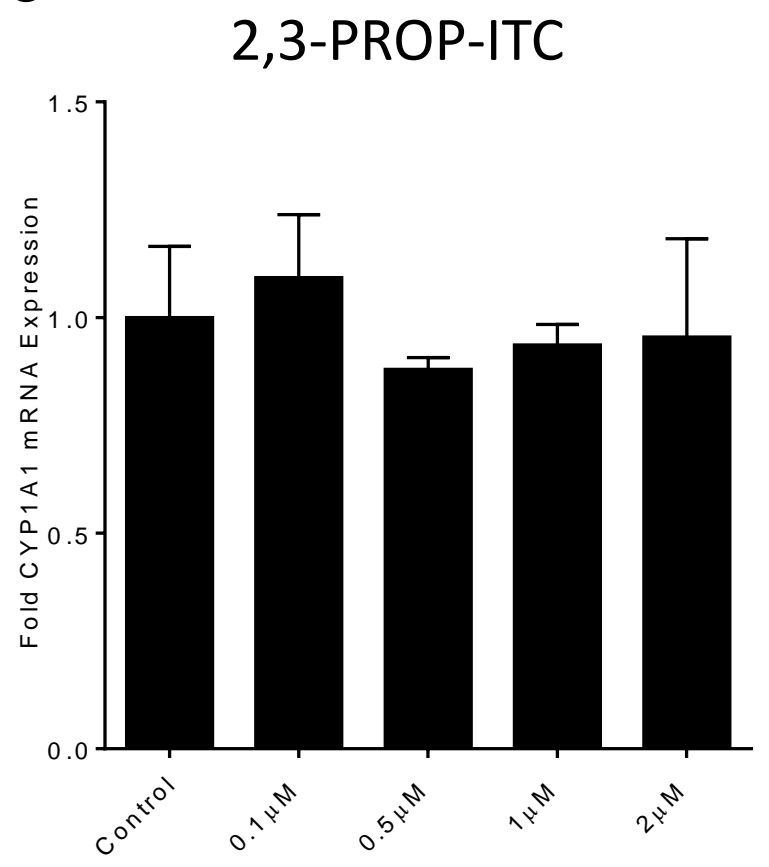




\section{Figure 5}
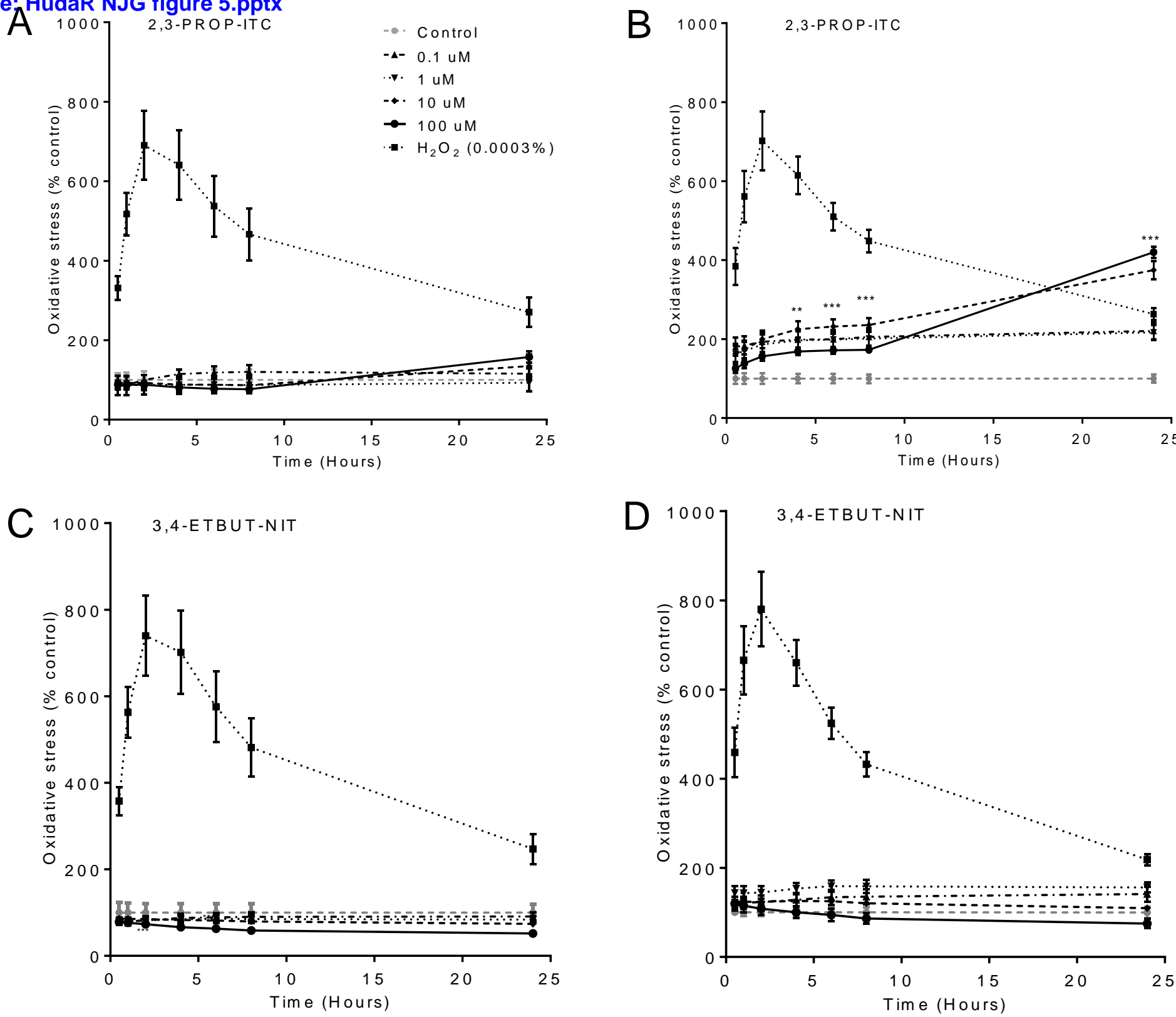
Figure 6
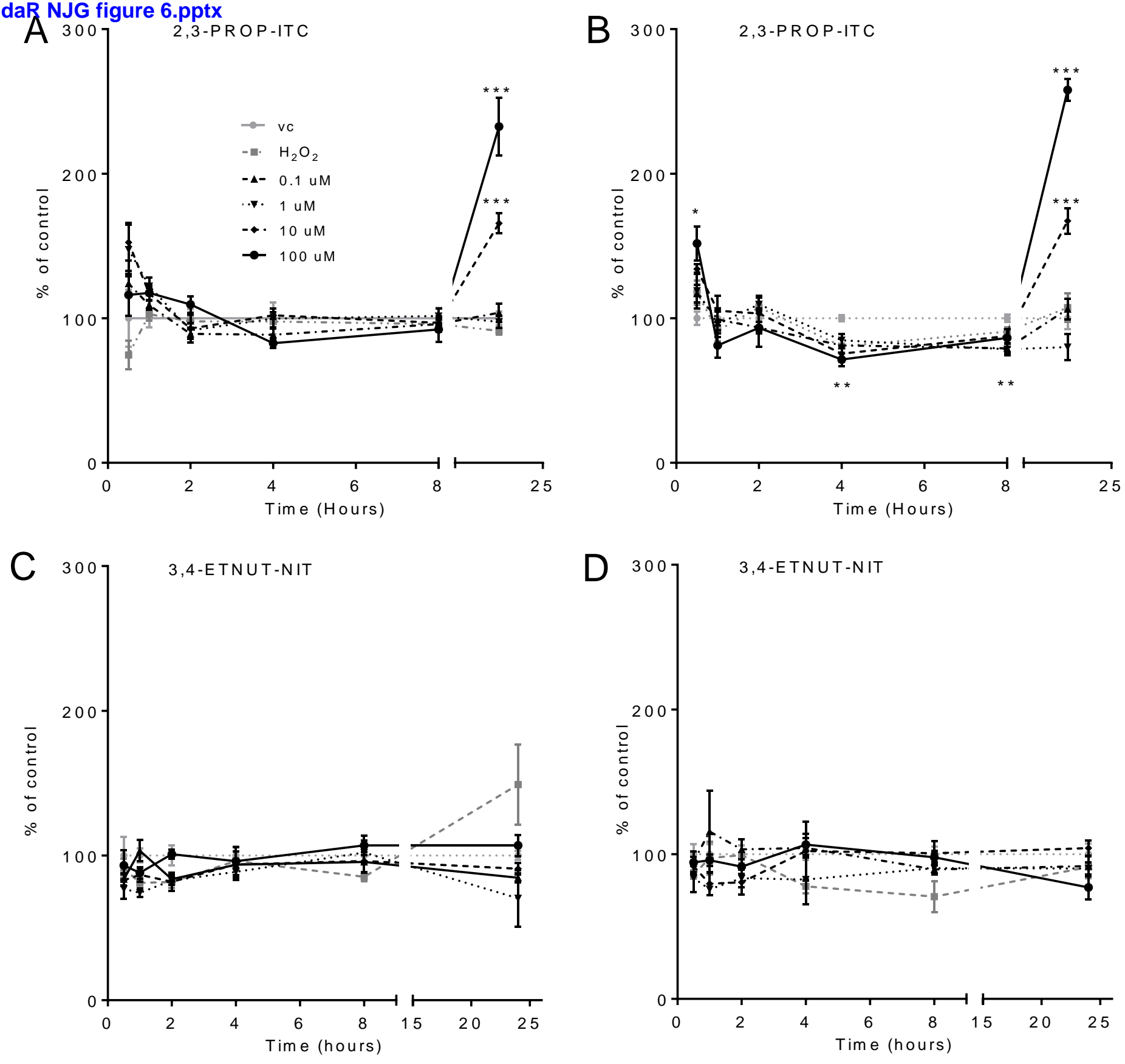
Click here to download Figure: HudaR NJG figure 7.pptx Figure 7
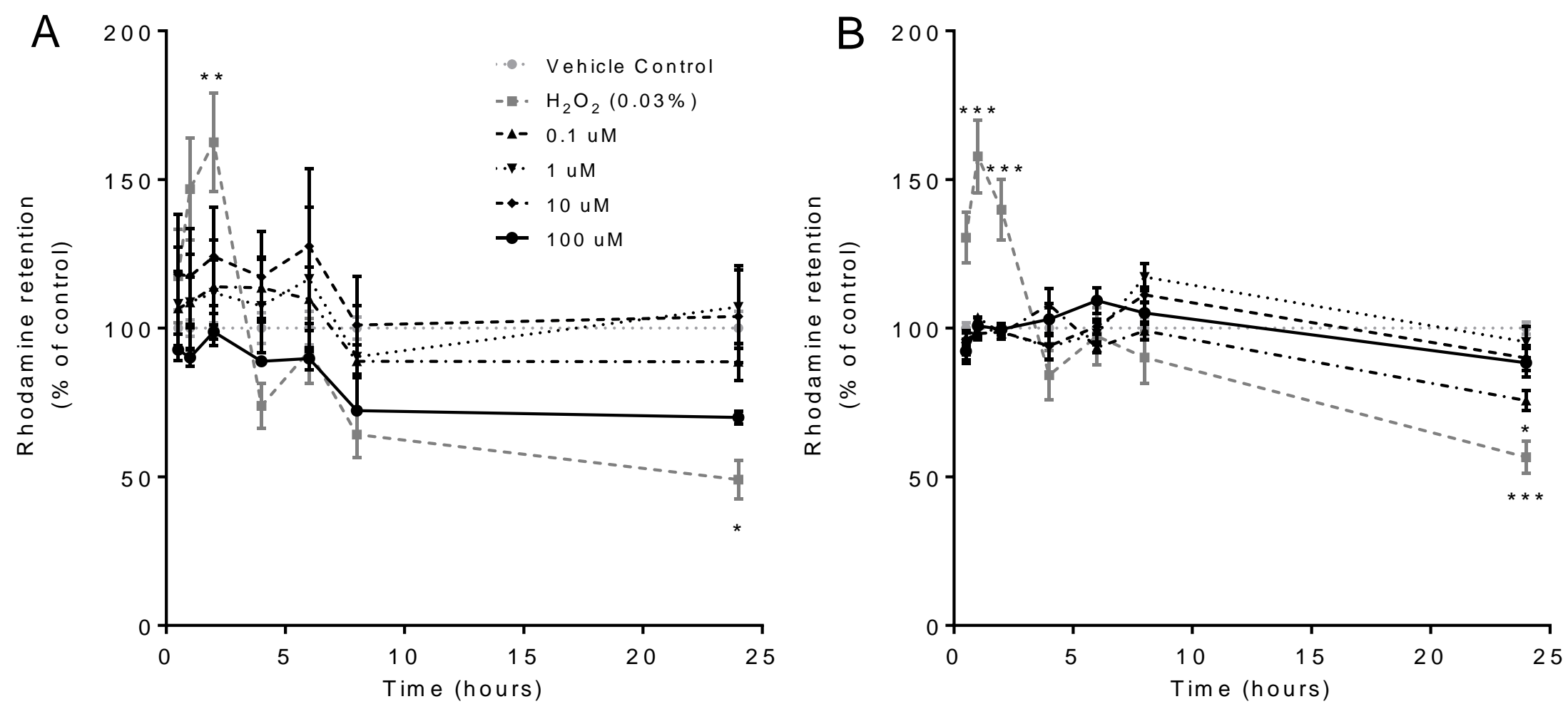


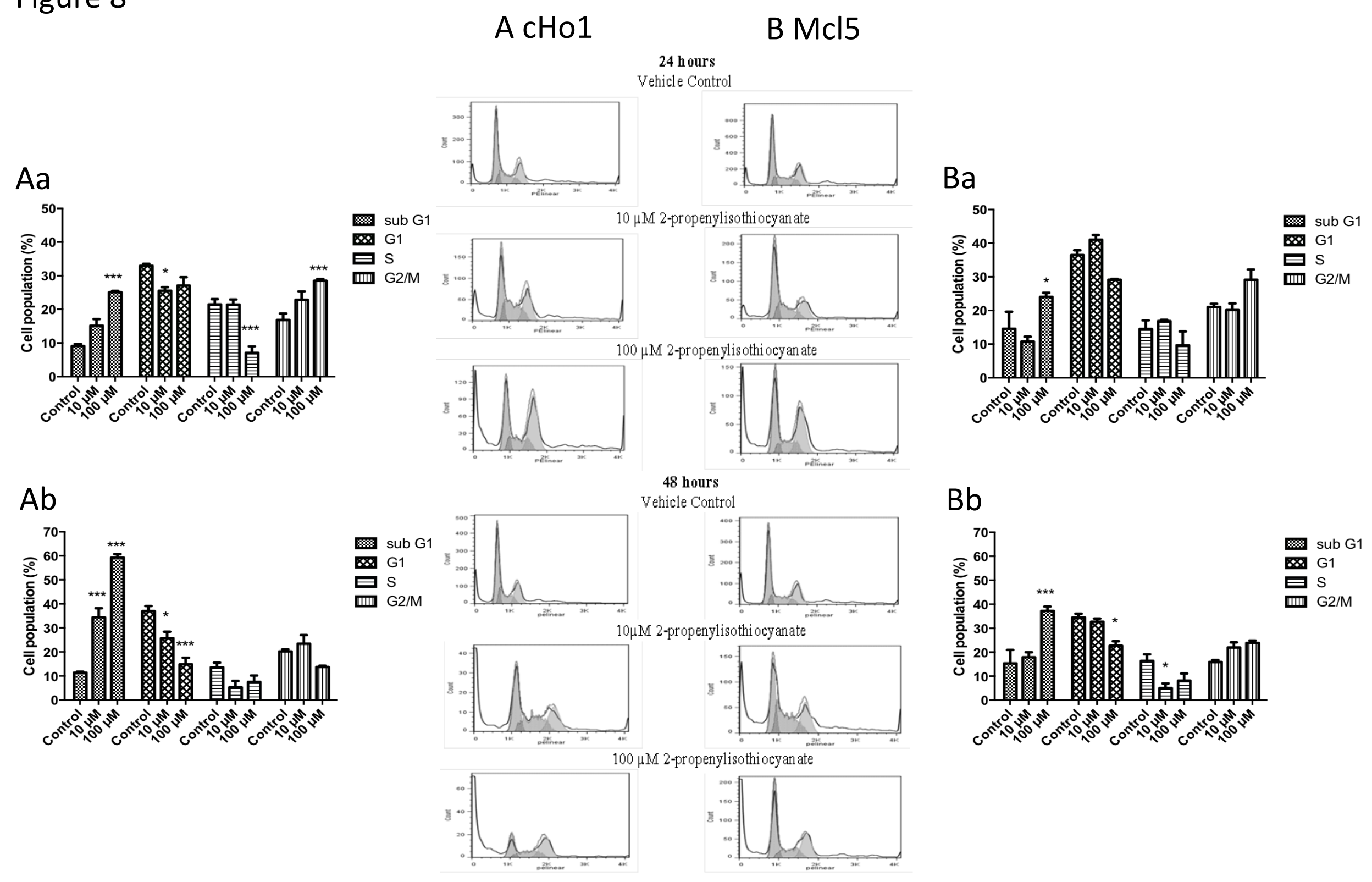

$\mathrm{Aa}$
A cHo1

$\mathrm{Bb}$ 


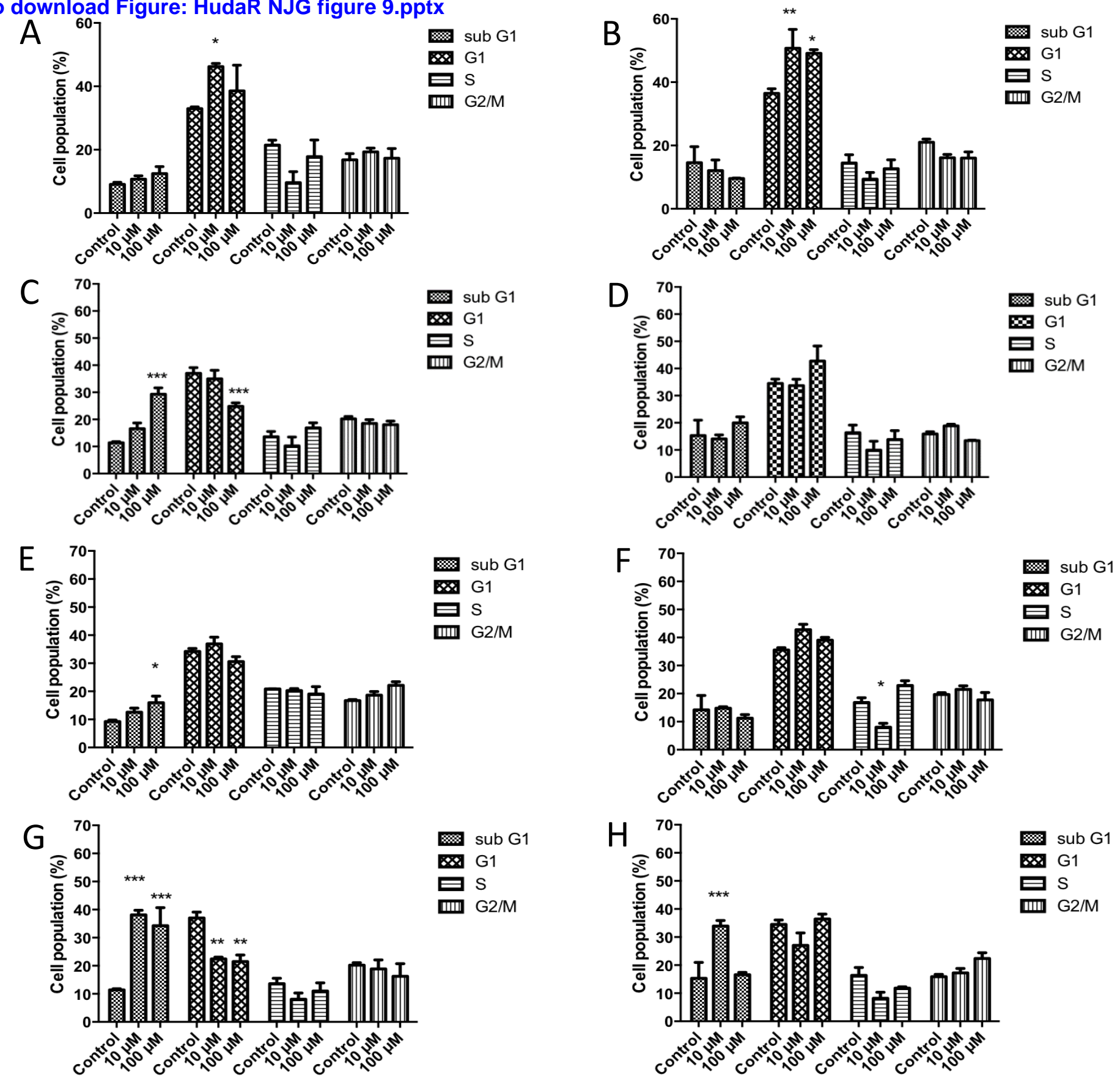

Figure 9 

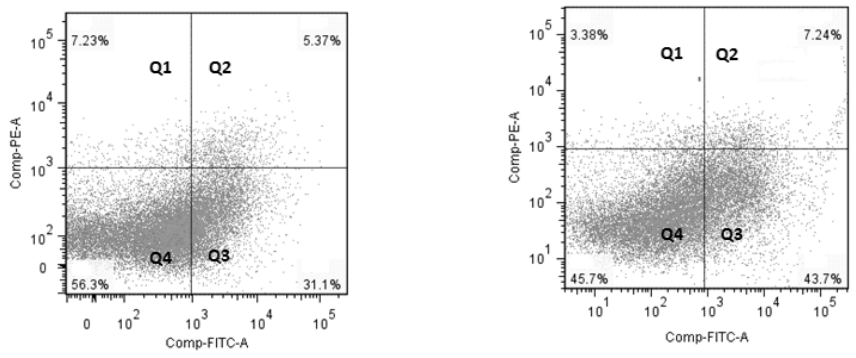

Control
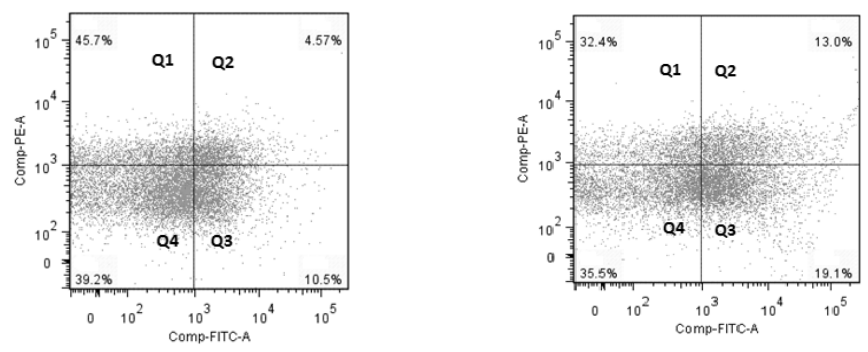

2-Propenylisothiocyate
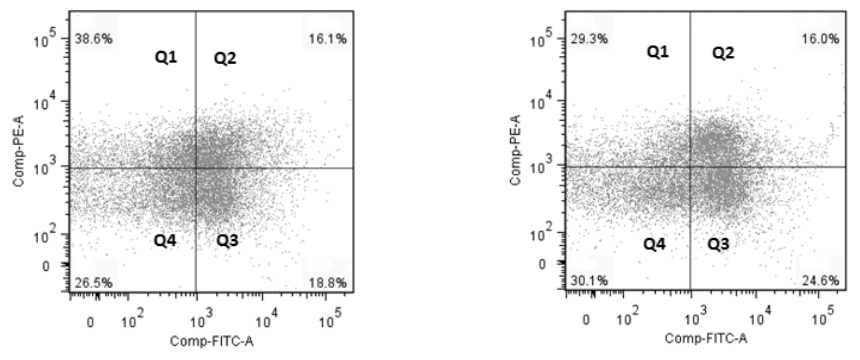

3-Butenylisothiocyanate
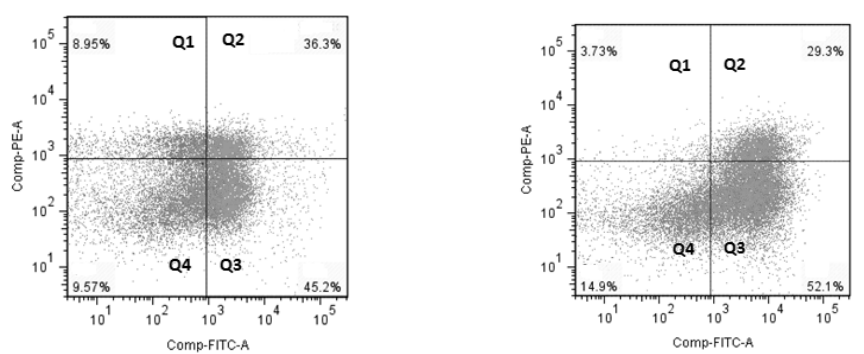

A a

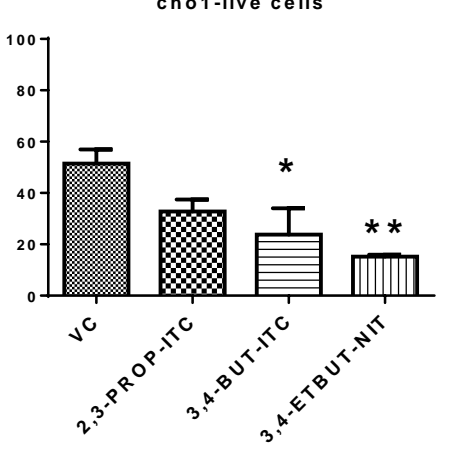

A b

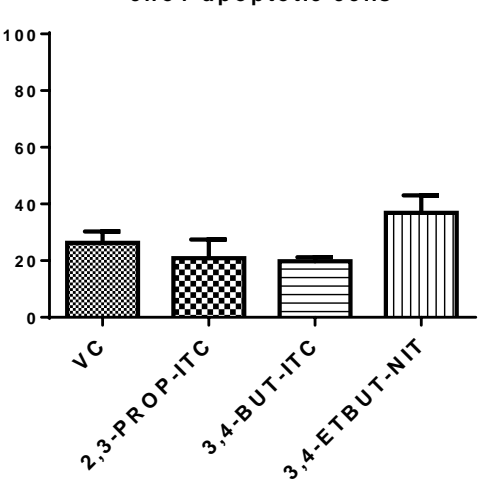

cho1-necrotic cells

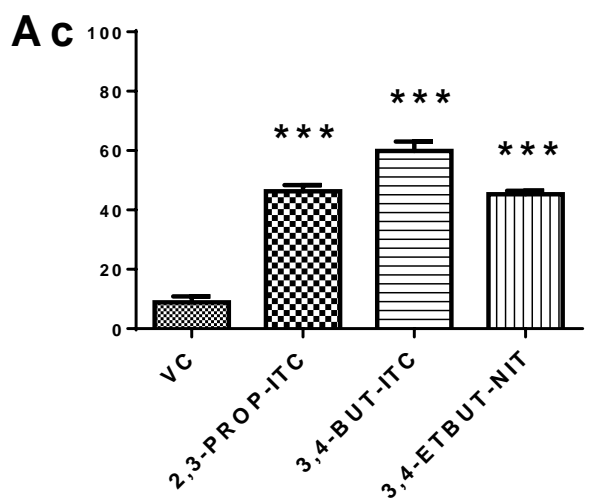

B a

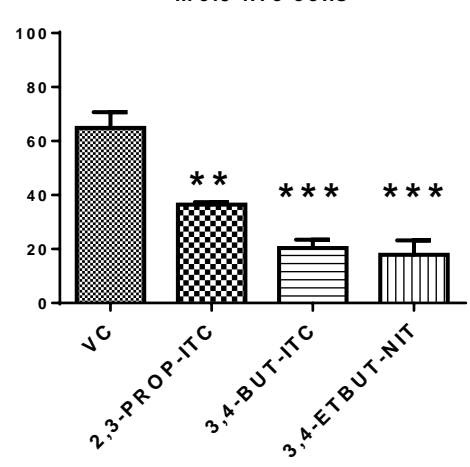

B b

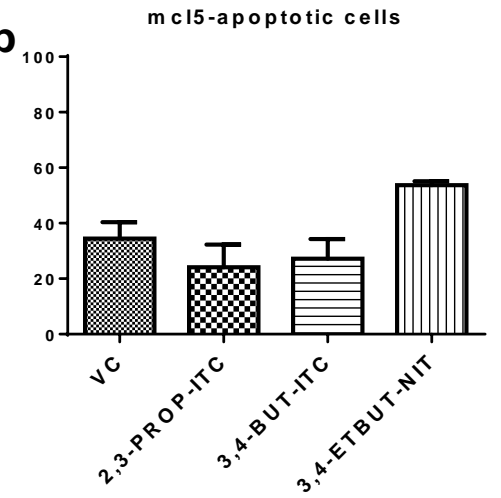

B C

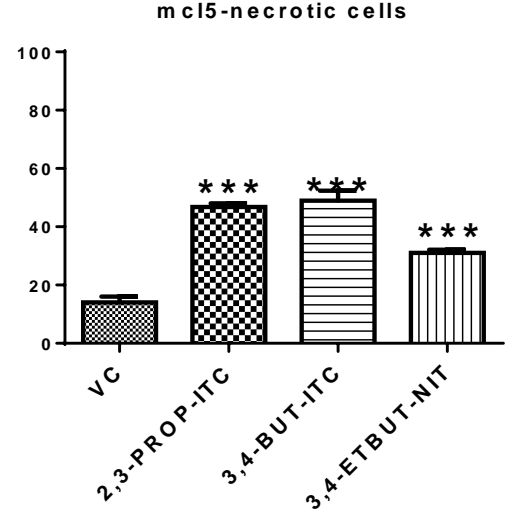

